\title{
Material Establishment and Public Display
}

\section{Sally M. Promey}

This short essay, as conceptual "mediation," offers preliminary exploration of a subject I elaborate in greater detail in my almost complete book manuscript on the public display of religion in the United States. ${ }^{1}$ In the book's final chapter, I center attention on the cultural politics of space in Hawai'i. In this much shorter mediation I invite Hawaiian materials and places into conversation to illuminate some of the American mechanics of material establishment. While this phenomenon turns out to be, I argue, a key manifestation of public display throughout the United States, it first came into clear focus for me in my consideration of the material situation of recent court cases in Hawai'i. Public display operates here, and in the continental USA, as a technology of nation formation and sovereignty claims of various sorts. The cultural politics of space has to do not simply with space itself, but with how it is occupied, enacted, performed, and marked-and sometimes, in Hawai'i and elsewhere, at least apparently unmarked.

In my longer manuscript, I address my attention to three aspects of Hawaiian religious geographies, first to what I call material establishment, second to the subject of cultural injury that is a frequent outcome of this sort of "establishment," and third to the issue of sovereignty. Each of these conditions is exacerbated in the Hawaiian case by the fact that the United States government quite literally stole the Hawaiian islands, illegally deposing Queen Lili'uokalani in 1893, ending the Hawaiian monarchy, and soon thereafter establishing Hawaii as a US territory, in the interests of capitalism, Christianity, empire, and militarization. The nation (lāhui) had already suffered dismemberment and dispossession at the hands of traders and missionaries (beginning as early as the "first contact" arrival of Captain Cook in 1778). ${ }^{2}$

These are immensely complicated subjects, any one of them, for a short essay. So for now I propose simply to offer these three ideas as possible analytical terms and then to all-to-briefly describe some current objects, spaces, and practices I hope the terms will eventually help me to understand and illuminate. Recent events in Hawai'i direct my energies toward O'ahu, Hawai'i Island, and Maui in particular. Here I grant most words to the subject of material establishment because this is a term I myself propose; and it seems to me to more urgently require definition, especially for its intimate relation to questions of cultural injury and sovereignty.

In all my work on Hawaiian geographies, I am deeply indebted to the scholarship of others, most especially Greg Johnson and Ty Tengan. ${ }^{3}$ Johnson's work, and Winnifred Sullivan's, most immediately inform my thinking about establishment. Johnson expands the notion of establishment beyond its narrower legal and constitutional senses to consider the "more general question of how the State regulates . . . religion ... whether by design, happenstance, or negligence."4 In Johnson's view, "'establishment' takes hold when[ever and wherever] the State shapes in some respect, however apparently minimal, the trajectory and expression of religious life." ${ }^{5}$ Johnson further describes three "heuristic modalities" of establishment by the State: while his first two categories 
are relevant to my subject, I take up here only the third, what he calls "naturalized establishment." Throughout the United States, as Johnson points out, naturalized establishment is the form that "mainline Christian churches have long enjoyed, enabling them to receive public funding in various contexts and to enjoy privileged locations, for example, in national parks." Naturalized establishment is a sort of "cognitive dissonance writ large." 7 My material establishment constitutes a distinctive subset of Johnson's naturalized establishment, operating often below the threshold of conscious awareness but contributing nonetheless to assumptions, expectations, and consequent decisions about religion (especially religion in public). Material establishment, particularly in relation to the ways a nation state divides or marks territory or property, and organizes its commercial, economic, and political life, can be as apparently innocent as prior presence on and claims to the land, resulting in prominence and accessibility and the cultural assumptions and allowances that attend them and thus subtly permeate decisions of consequence by public officials in all branches of governance. The "matter" that shapes material establishment often precedes actual action by the State, though this is not always the case. The conditions for material establishment rest on the kind of persistence and reiteration that secure a degree of eminence in under-the-radar notions of national identity and national assumptions about what properly constitutes "religion"-and thus influence decision-making at all governmental and administrative levels.

As an initial example, I offer the current dispute between Kawaiaha'o Church (Fig. 1), with its plans for facilities expansion, and those who wish to protect ancestral burials and human remains on the construction site. This case might also be approached from the perspectives of cultural injury or of sovereignty. Naturalized establishment, in its general and spatial/material forms, is already both species and cause of cultural injury. In Hawai'i, furthermore, virtually no dispute is untouched by contestations about sovereignty. In Hawai'i, in fact, cultural injury is religious injury, since it is impossible to neatly separate religion from culture in Hawaiian practice. This thorough permeation of culture by religion presents serious obstacles to the structures and underlying conceptualization of the US legal system vis-à-vis religion. ${ }^{8}$

As Johnson also suggests, the conflict at Kawaiaha'o Church (Fig. 2), a congregation of the liberal Protestant denomination of the United Church of Christ, foregrounds a number of central concerns for Hawaiian religion. Most important, it (first) demonstrates the fundamental significance for indigenous practice of care for ancestral remains and ancestral burials, the mana or spiritual power of these objects, as well as the ritual protocols by which they must be engaged to ensure proper kuleana (responsibility/authority). Malama na iwi (caring for the bones) is essential to Native Hawaiian religious practice. Second, the Kawaiaha'o case demonstrates the degree to which various forms of Christian practice have, in this colonial context, become inextricably integrated with indigenous religious identities. Despite indigenous opposition at Kawaiaha'o to the church's actions, the church itself has an indigenous pastor and conducts parts of its service in Hawaiian. Trying to separate "Christian" from "indigenous" (from the outside) amounts to a nonsensical and ultimately patronizing gymnastics, as apparent in this textual rejoinder on Maui (Fig. 3) where KE AKUA 


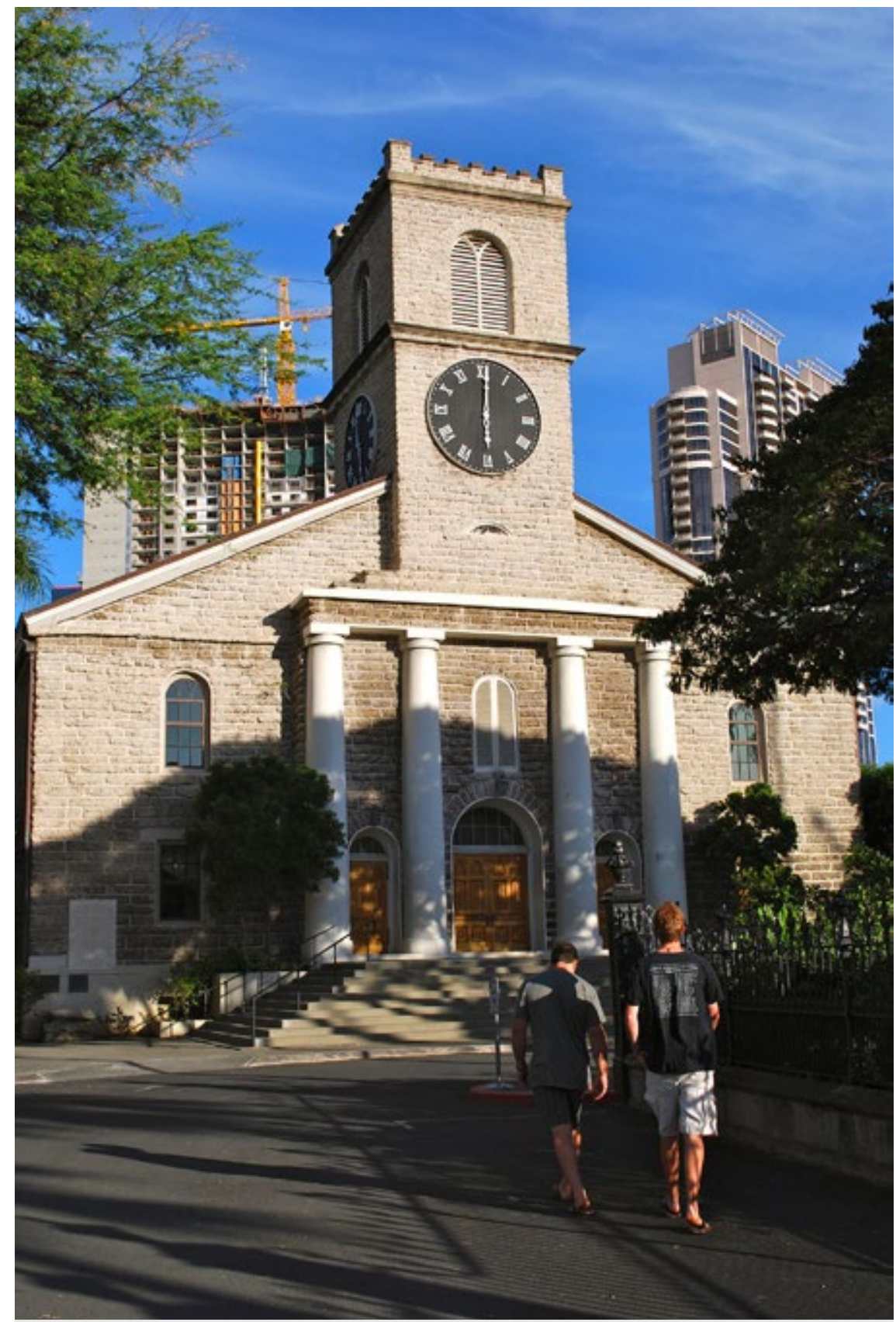

Fig. 1 Kawaiaha'o Church, O'ahu, main façade, July 2014. Photo: (c) Sally Promey

(literally "The God," and in this format unambiguously signifying the Christian god) is inserted as testimony in opposition or addition to the demarcation of traditional Hawaiian practice. ${ }^{9}$ At Kawaiaha'o, this set of relations necessitates attending to the specific forms of naturalized and material establishment granted to or claimed by the church and to the specific cultural injuries sustained. The complexities introduced by this calculus are not unique to Hawai'i but they do have special resonance here, especially in relation to current sovereignty movements and their possible outcomes.

The dispute at Kawaiaha'o centers on a church building expansion project (Fig. 4) 


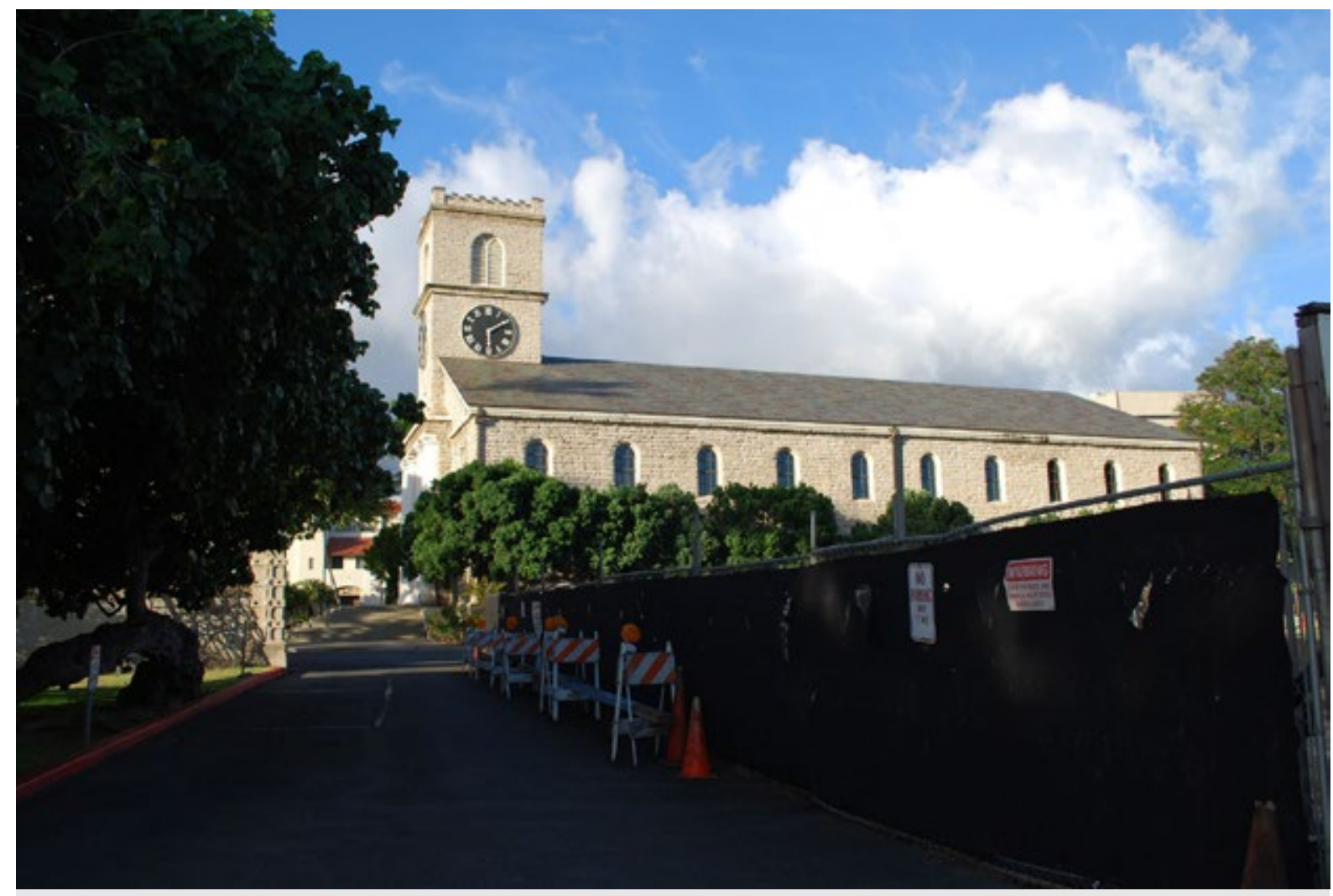

Fig. 2 Kawaiaha'o Church, O‘ahu, construction site fencing and barricades, July 2014. Photo: (c) Sally Promey

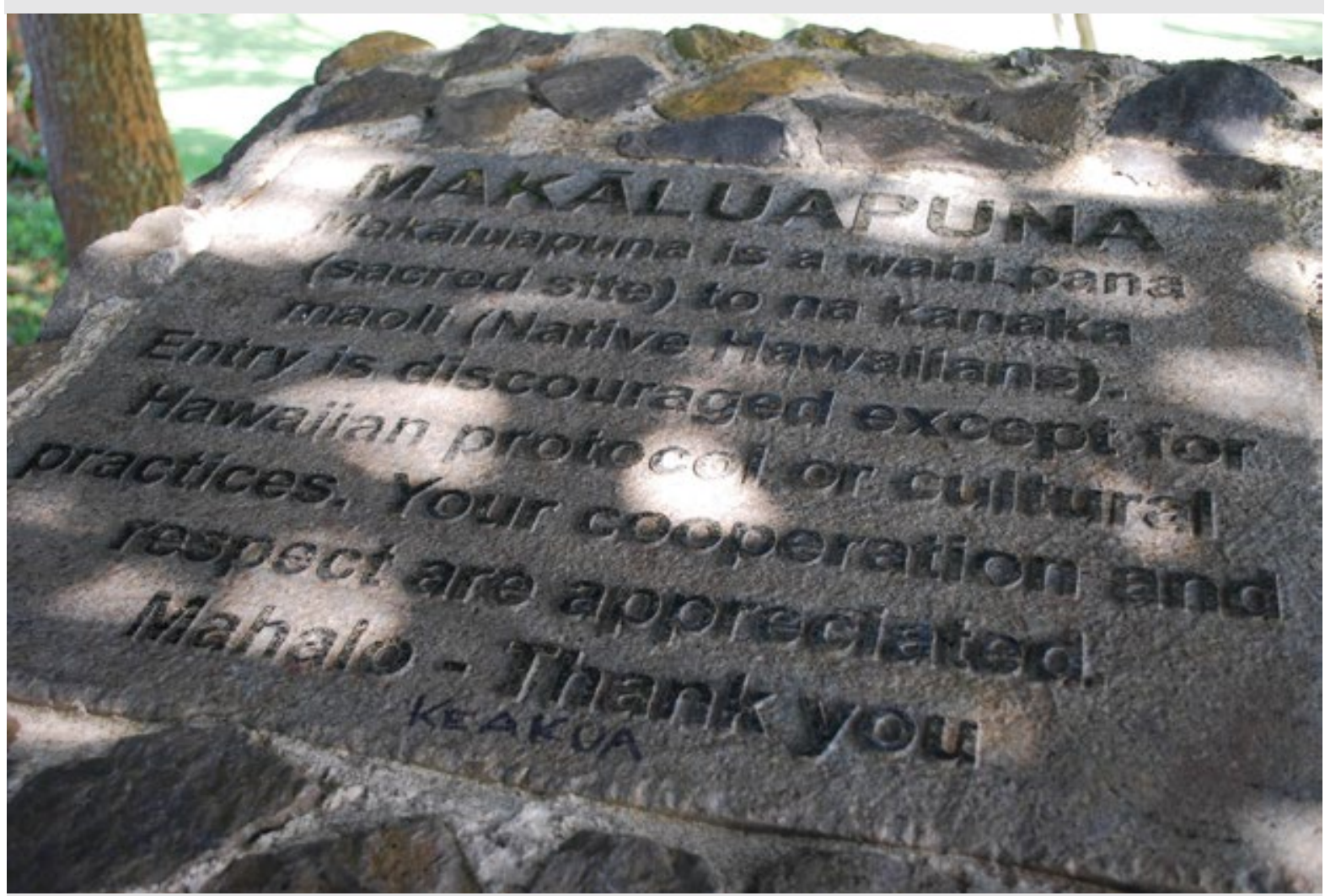

Fig. 3 Makāluapuna sacred site, Maui, stone marker with plaque, note addition of KEAKUA in permanent marker, July 2015. Photo: CSally Promey 


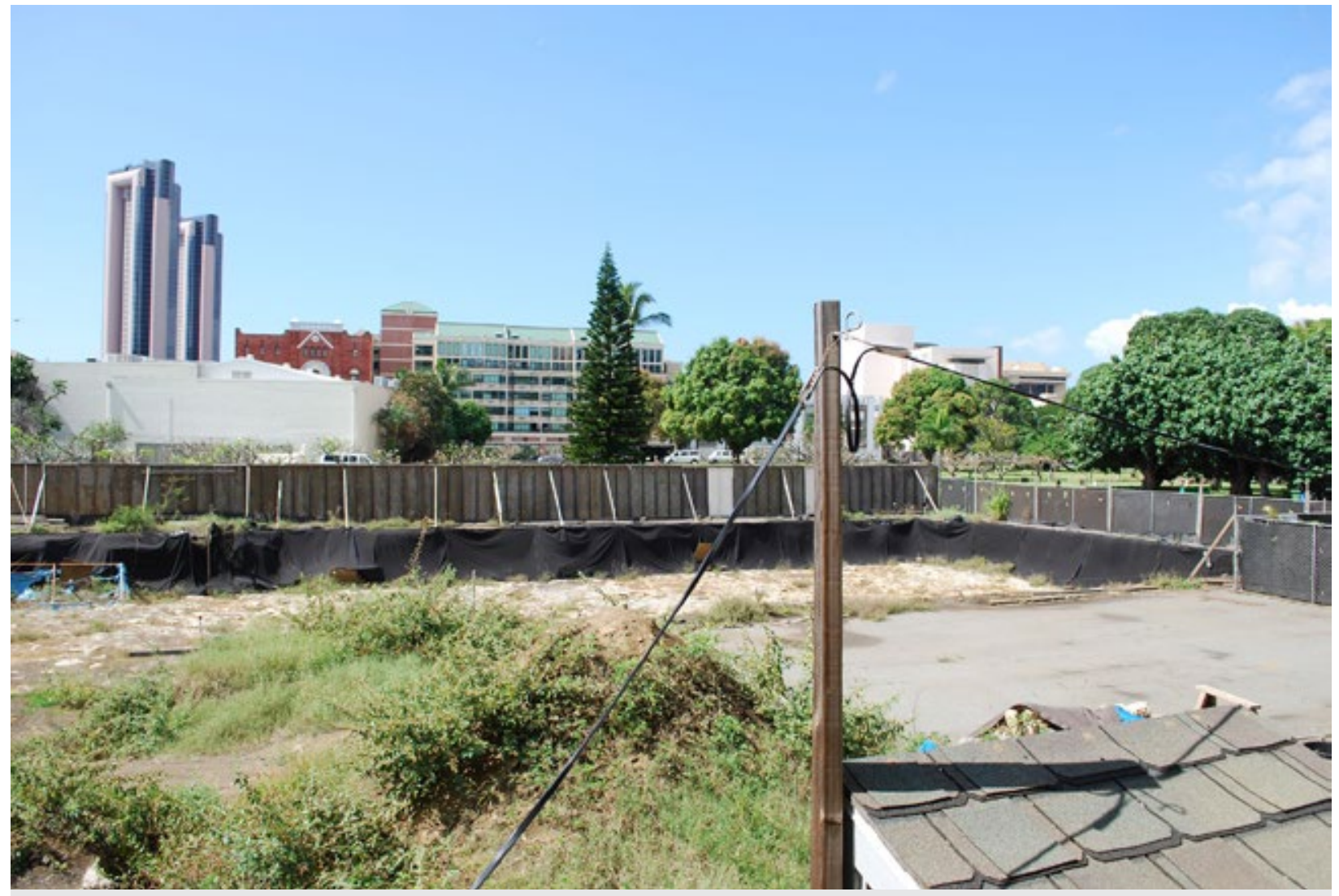

Fig. 4 Kawaiaha‘o Church, O‘ahu, construction site, looking out side door near front of sanctuary, February 2014. Photo: (C)Sally Promey

that began in 2009 and on the literally hundreds of burial disturbances that have resulted. The case is ongoing and, after a perplexing series of judicial decisions that allowed the church to proceed with excavation, the archaeological inventory that should have been conducted before burials were disturbed has finally been ordered in just this past year (2015). Johnson's magnificent article on "Varieties of Native Hawaiian Establishment" provides the legal details of the case over time, at least through August 2012 when he completed the essay. I have visited the church several times, to get a sense of the worship service and the site, and to speak with congregants. I also attended an August 2014 court hearing on the case. Importantly I should note the prominent large-scale bronze relief sculpture (Fig. 5) at the entrance to the Hawai'i First Circuit Courthouse where the case is currently being heard. This work of art depicts the queen Ka'ahumanu who, immediately after the death of Kamehameha I in 1819, ended the indigenous 'aikapu ritual system. Protestant missionaries arrived in the islands in 1820 and Ka'ahumanu and many other ali'i (royalty and elite) converted to Christianity. This is precisely the history told in the sculpture's inscription (Fig. 6). The courthouse sculpture, in the selection of this particular subject (the queen who dismantles traditional religious practice and oversees conversion to Christianity) constitutes an example of what I am calling material establishment, a kind of "soft" but pervasive set of under-the-radar material and spatial claims. The courthouse building, in fact, is named Ka'ahumanu Hale (house; Fig. 7). This sort of material establishment is directly related 


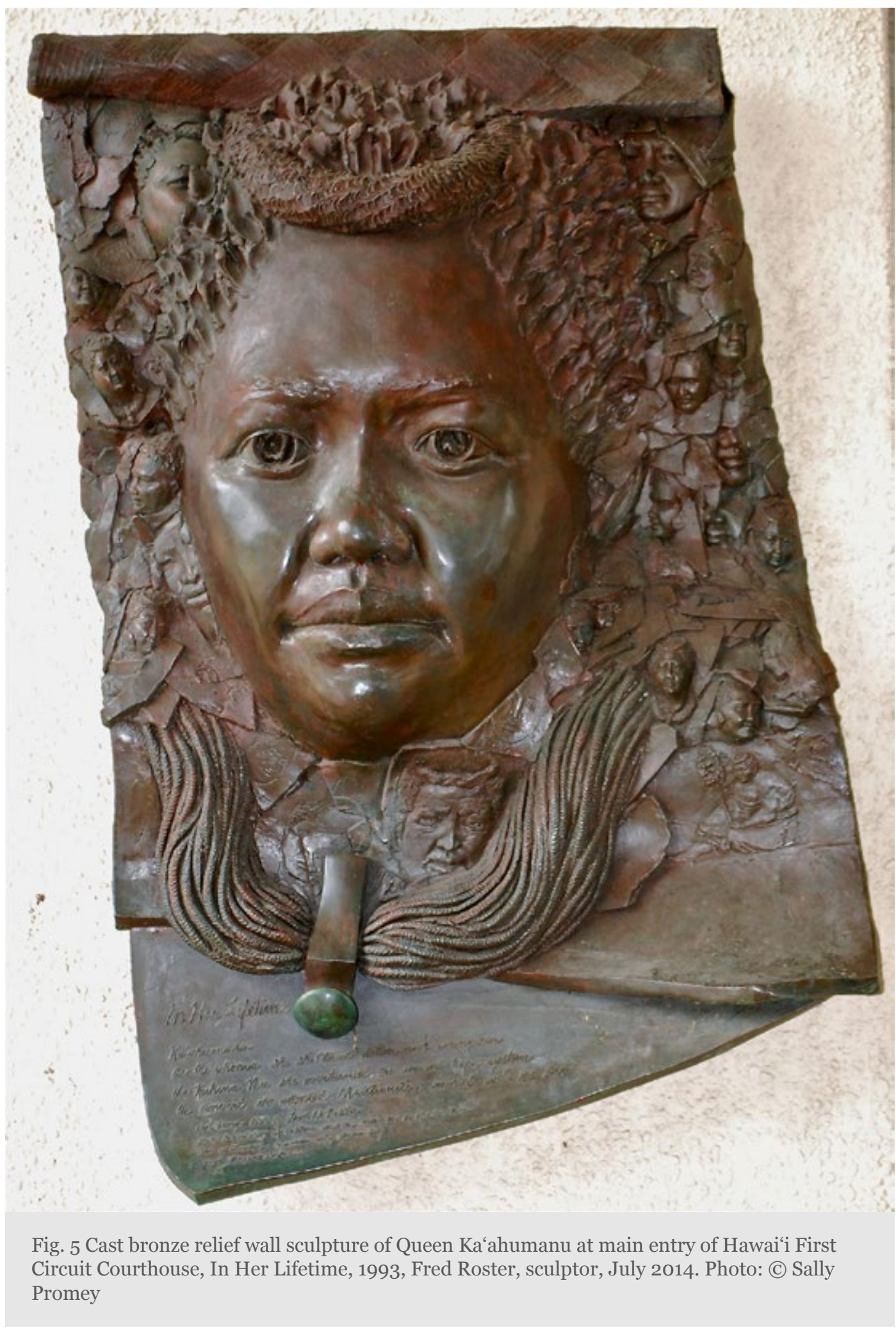




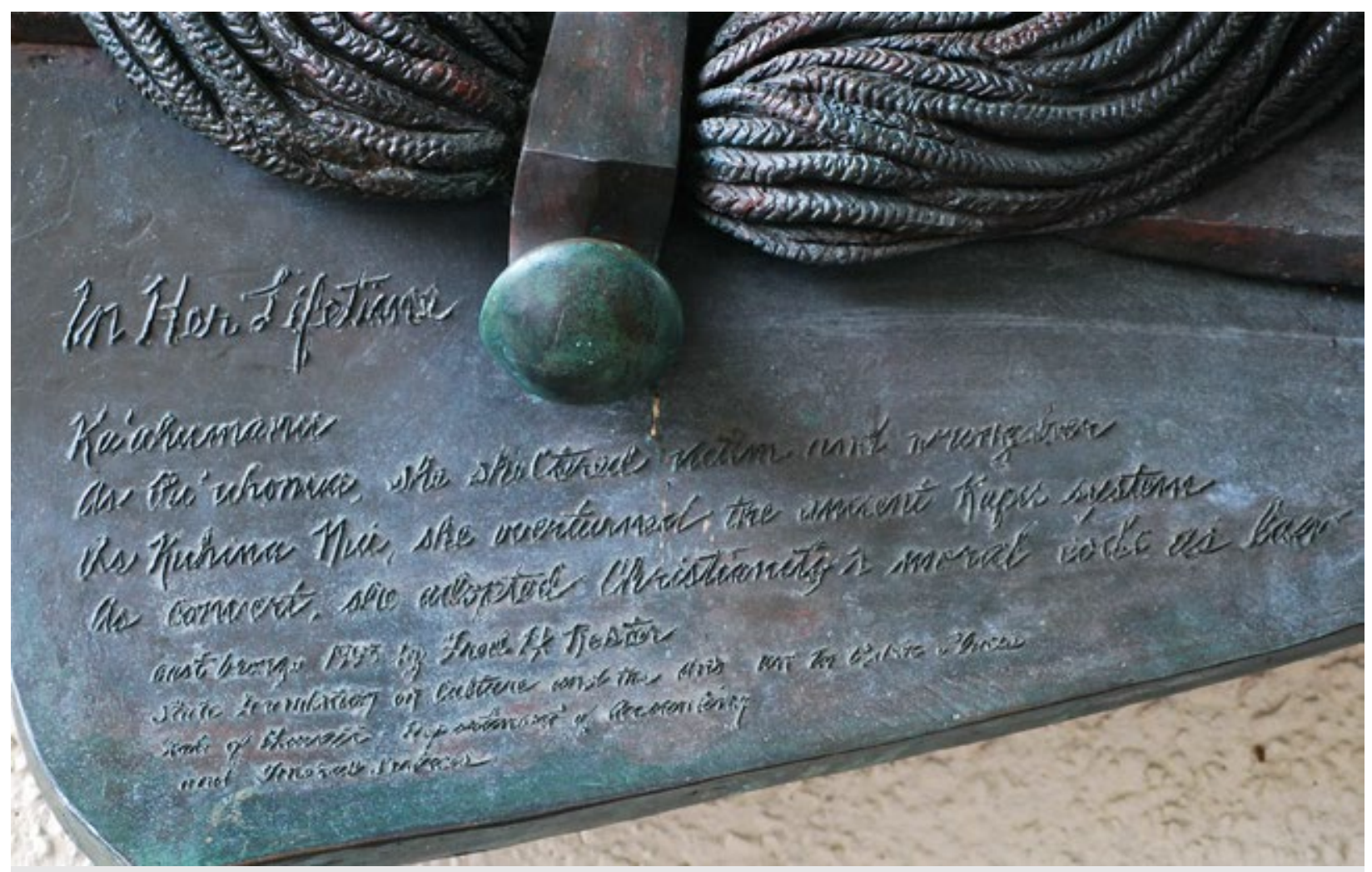

Fig. 6 Detail of In Her Lifetime, showing inscription, July 2014. Photo: (C) Sally Promey

to the religious heritage industry and its historical claims to the land, not only in Hawai' $\mathrm{i}$ of course, but also elsewhere in the United States, underscored by such seemingly simple things as informational signage throughout the US Highway System and its smaller scale local tributaries (Figs. 8 and 9).

To return to the church itself: the first flank of Congregationalist missionaries to the islands founded Kawaiaha'o church. As Hawaiian royalty on O'ahu converted to Christianity, the congregation came to function as the national church of the Kingdom of Hawai' $i$, overseeing coronations, royal weddings, and funerals. The current building, the "Great Stone Church" (built from coral) was dedicated in 1842, attended by royal fanfare and an estimated 5000 worshippers. It is a registered United States National Historical Landmark. Its sense of itself, as represented in the language on its website, its material presence on the land, its interior and exterior decoration (Fig. 10-11), and its ritual life underscore this past status though the congregation now numbers only about 150 members. The masthead of its official website identifies the church in the present as "The Westminster Abbey of the Pacific," a reference that accomplishes cultural and political work in terms of its claims to establishment, staking a specific historical position in relation to Hawaiian sovereignty by referencing a monarchical ecclesiastical institution and a British one at that. This church (but by no means all Hawaiian sovereignty claimants) thus construes its own direct connections to a Hawaiian kingdom rooted in the monarchy of the British-influenced Kamehameha I who violently unified the islands largely to earn Western recognition $a s$ a sovereign and civilized nation. ${ }^{10}$ 


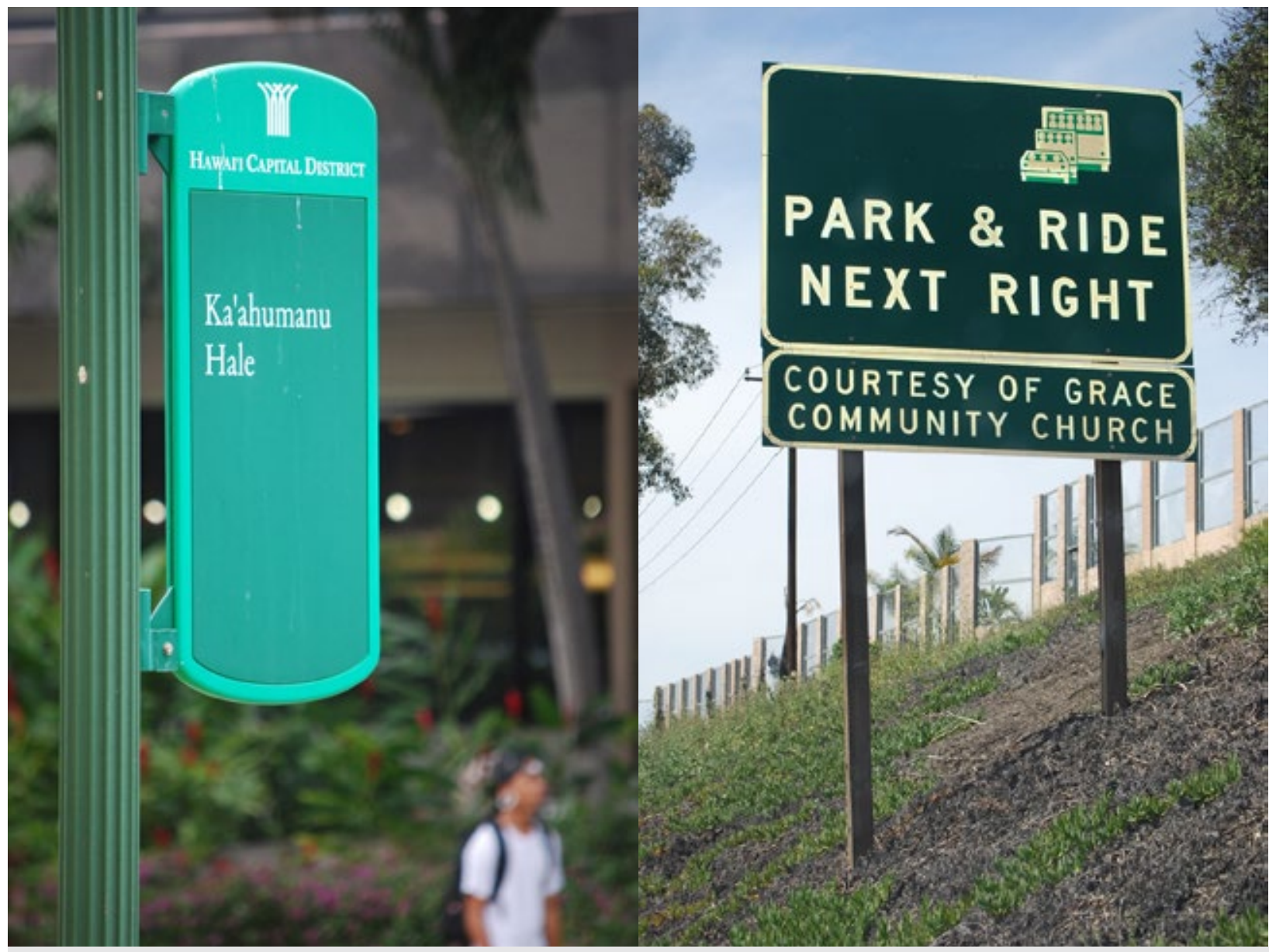

Fig. 7 Hawai'i Capital District signage, Ka'ahumanu Hale (or Hawai'i First Circuit Courthouse), July 2014. Photo: (C) Sally Promey
Fig. 8 Park and Ride Highway Signage, Grace Community Church (Lake Forest, California), as seen traveling north on Highway 5, March 2015. Photo: (C) Sally Promey

Kawaiaha'o Church's home page also asserts that people call it "The State Church of Hawai'i." It celebrates Ali'i Sundays seven times a year, asserting its maintenance of ritual connections to a royal elite past. The state infrastructure of the Hawaiian kingdom grew in immediate proximity to the church, with the nineteenth-century seat of the monarchy located in 'Iolani Palace (Fig. 12) on an adjacent lot across South King Street. Honolulu City Hall (Figs. 13 and 14) is also just across the street and the statue of Kamehameha I (Fig. 15) in front of the Hawai'i State Supreme Court (in Ali'iolani Hale) is visible from the church's front steps. The seat of the legislature (Fig. 16), the public library, and other public departments and offices occupy the immediately surrounding Capital District, a case of material, geopolitical establishment of the most obvious sort, and one that has played a key role in the unfolding of this dispute. Because the church so visibly occupies a large key parcel of land, in ways that make demands on Hawaiian missionary and monarchical histories, the authority of this church and its kahu or pastor has seemed to the courts, until very recently, to be irrefutable. Seasoned Hawaiian burial rights activists (Dana Naone Hall in particular) have argued otherwise-and the laws on the books clearly support the activists' claims. 


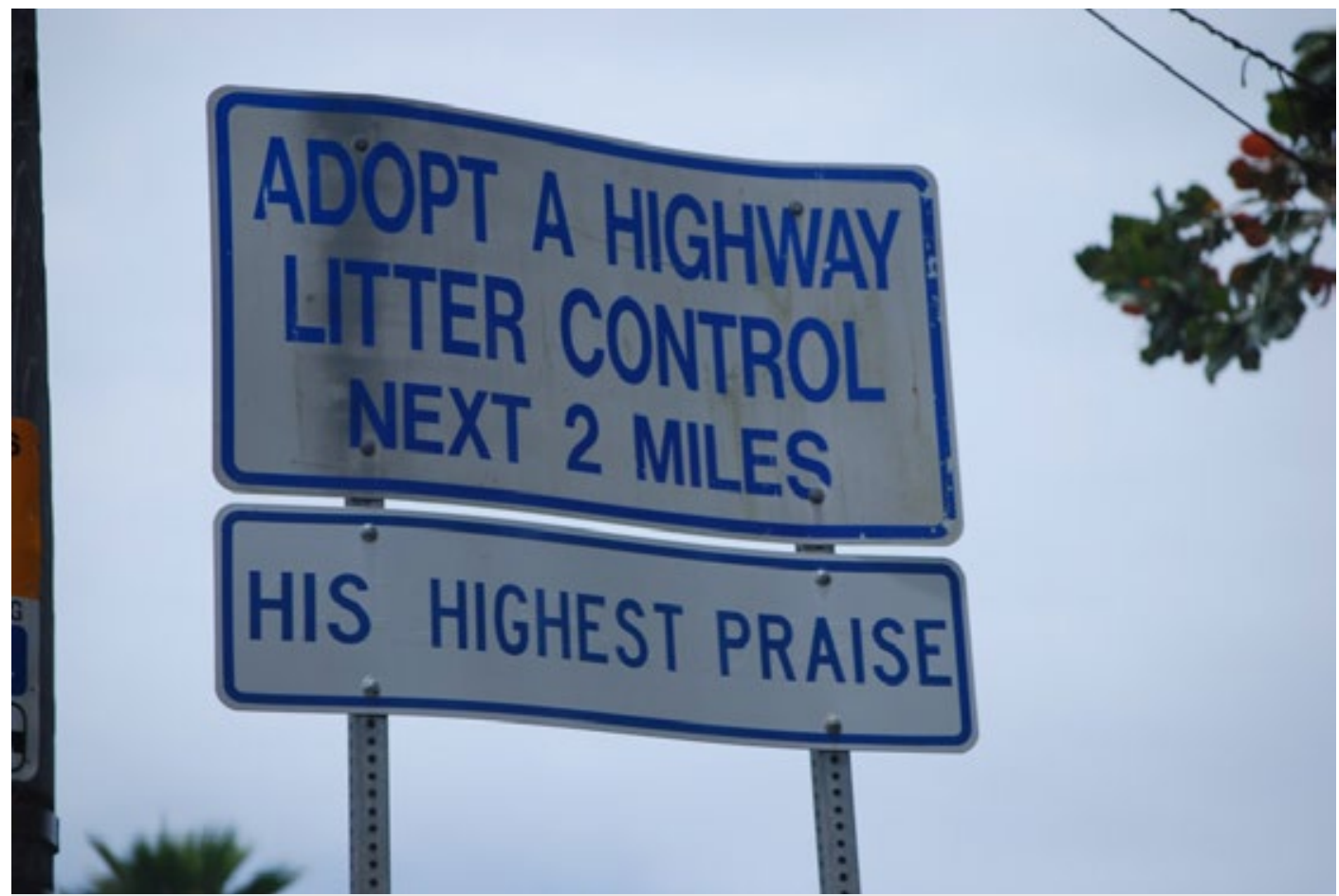

Fig. 9 Adopt a Highway Litter Control Signage, His Highest Praise, O'ahu, July 2014. Photo: (C) Sally Promey

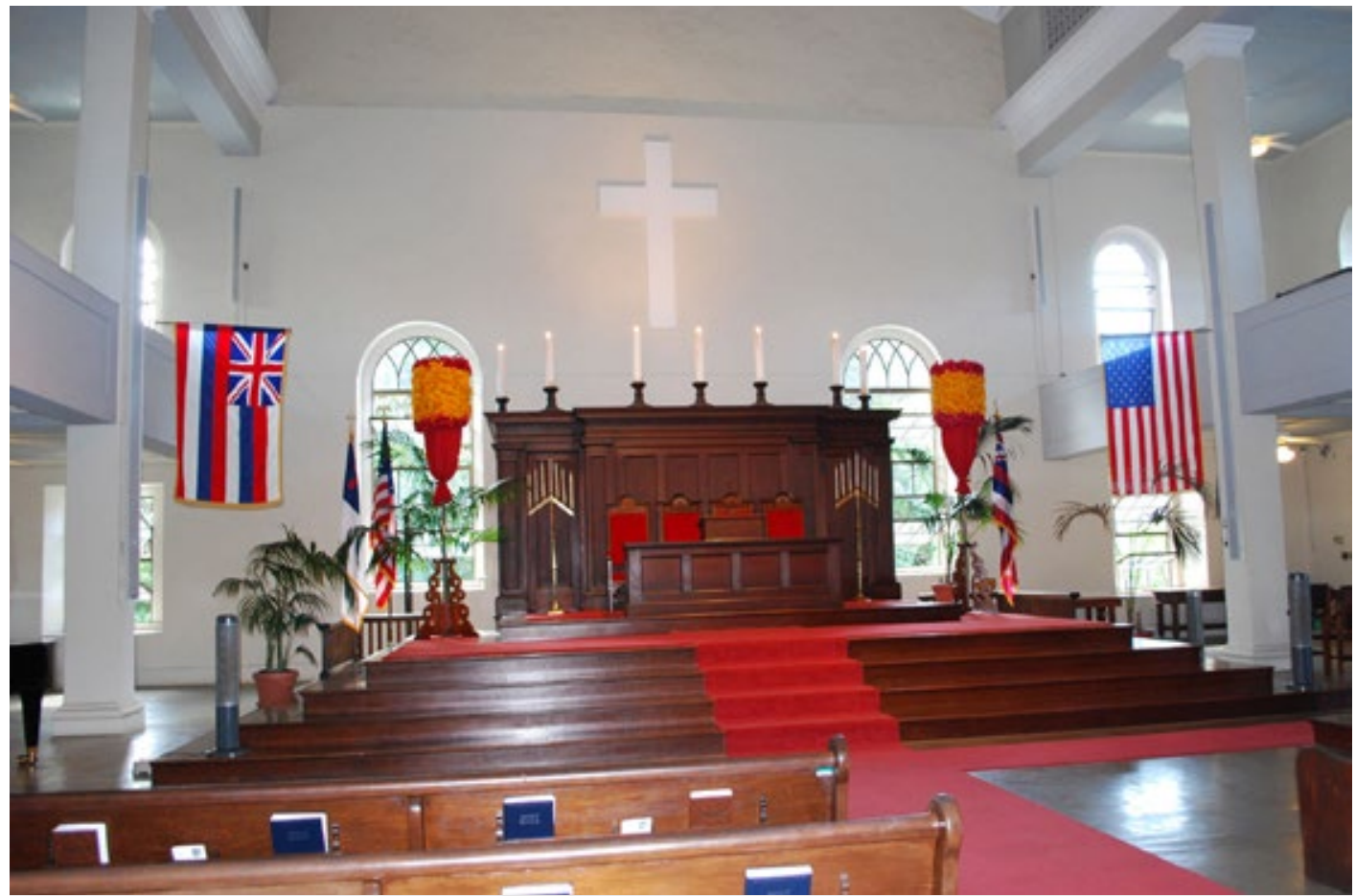

Fig. 10 Kawaiaha'o Church, O'ahu, interior, looking toward altar. Note red and yellow royal feather standards; alternating State of Hawai'i and United States of America flags flanking sanctuary (flags alternate from front to back and right to left along the full length of the nave); and, left to right, Christian, United States of America, and State of Hawai'i flags across front wall under white Latin cross, February 2014. Photo: @Sally Promey 


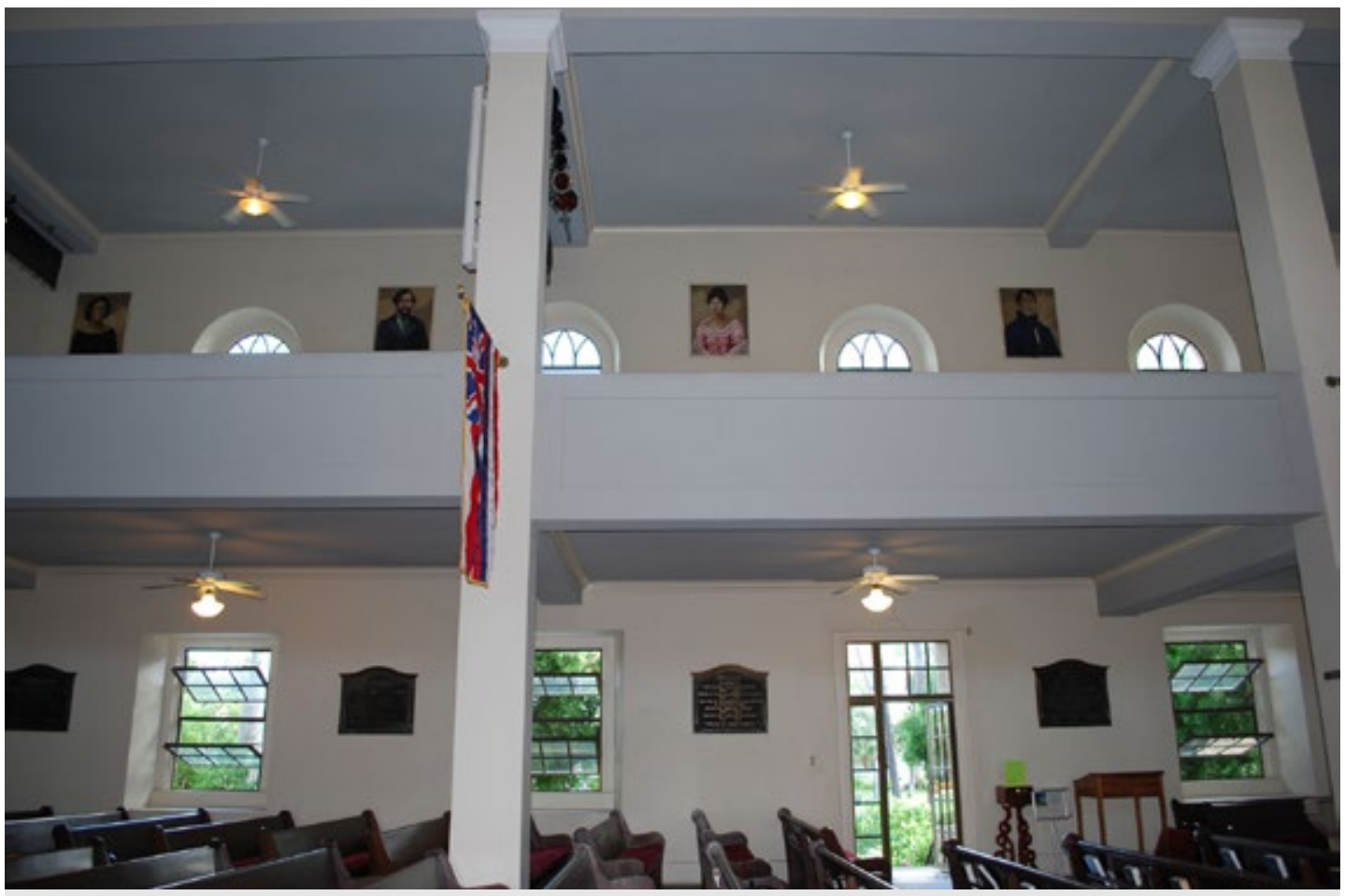

Fig. 11 Kawaiaha‘o Church, O‘ahu, interior, showing royal portraits and commemorative plaques in balcony and side aisles, February 2014. Photo: (C) Sally Promey

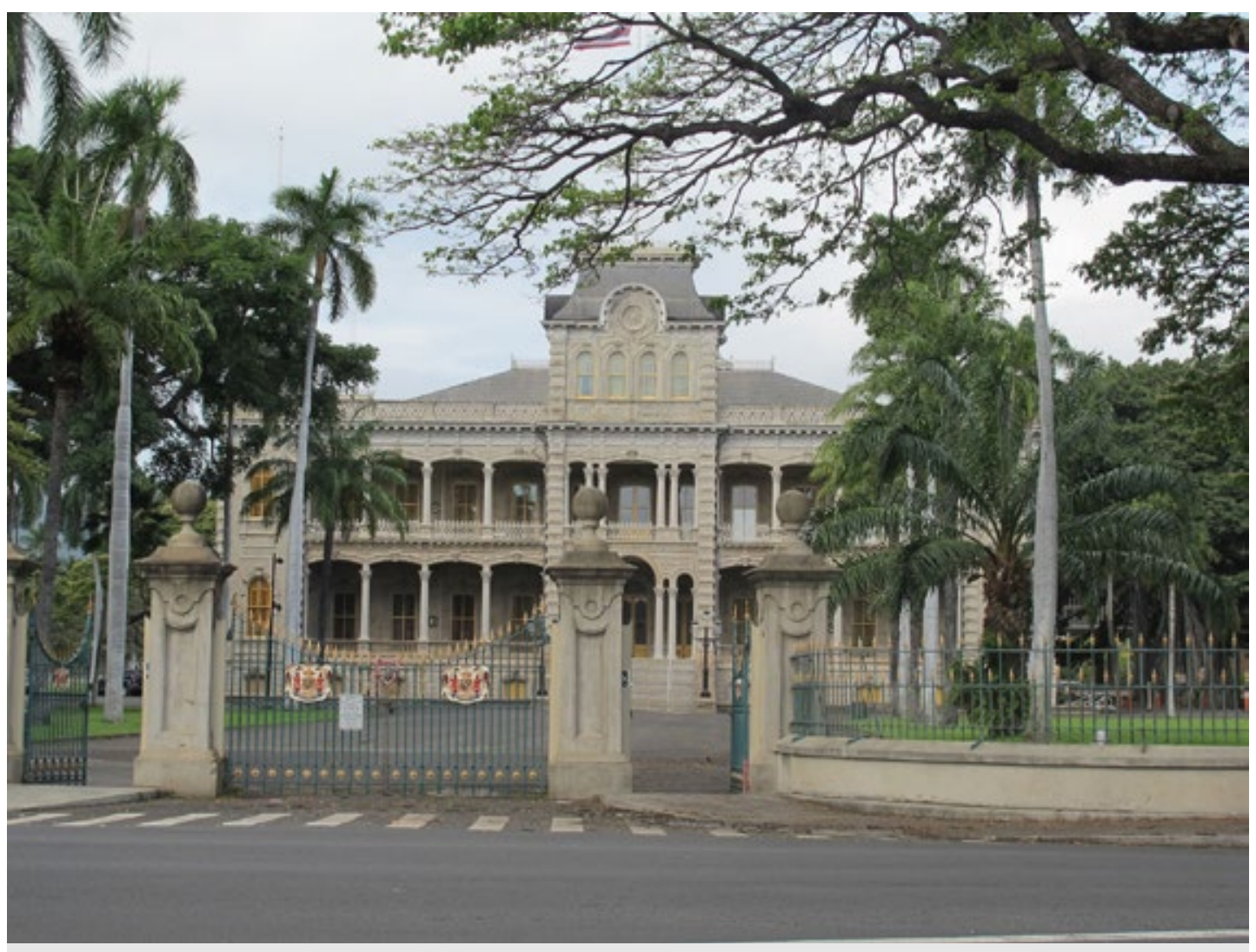

Fig. 12 ‘Iolani Palace, O‘ahu, May 2011. Photo: (c) Sally Promey 


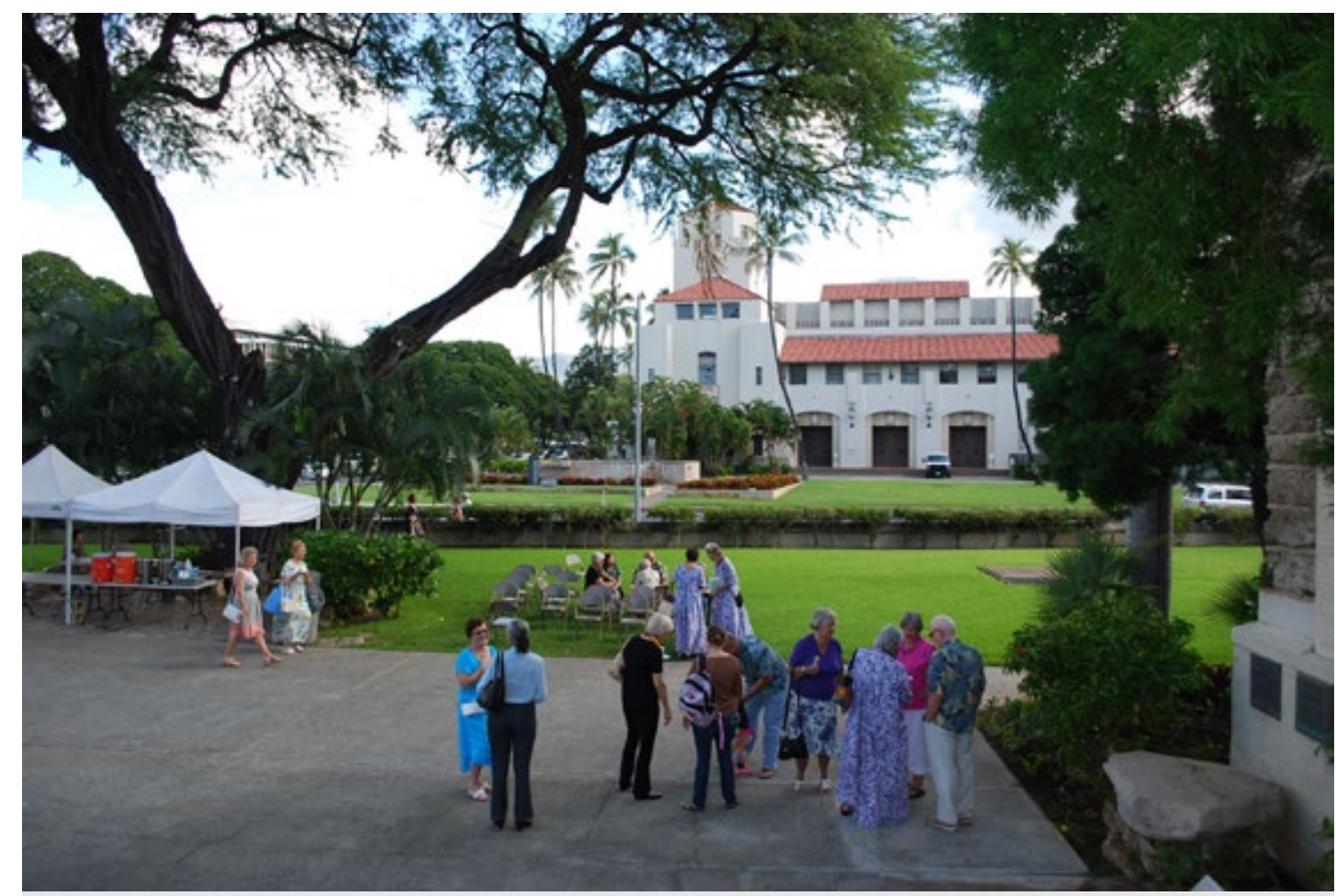

Fig. 13 Honolulu City Hall, O‘ahu, as seen from front steps of Kawaiaha‘o Church during Sunday coffee hour, February 2014. Photo: (C) Sally Promey

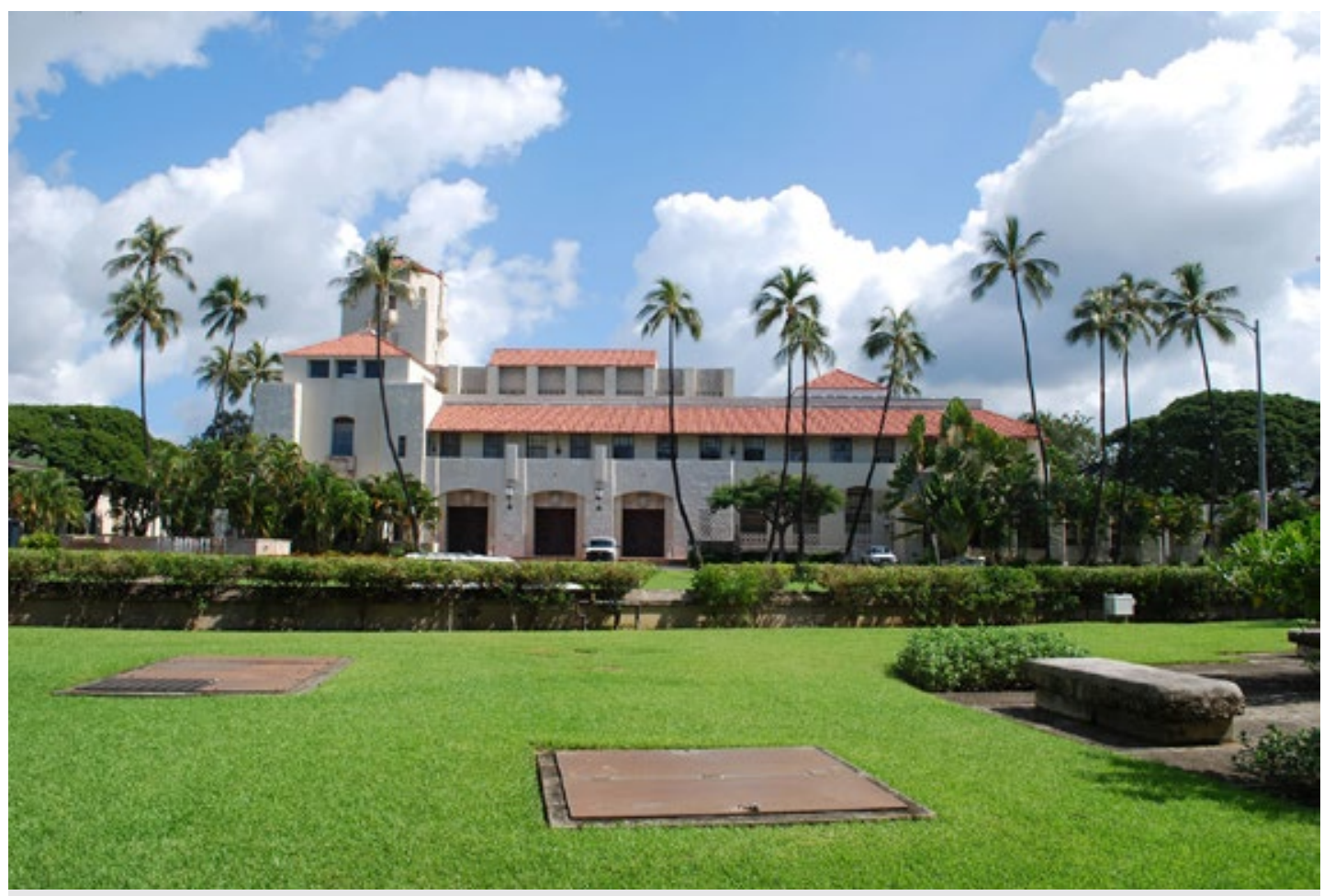

Fig. 14 Honolulu City Hall, O'ahu, looking across South King Street from Kawaiaha‘o Churchyard, February 2014. Photo: (C) Sally Promey 


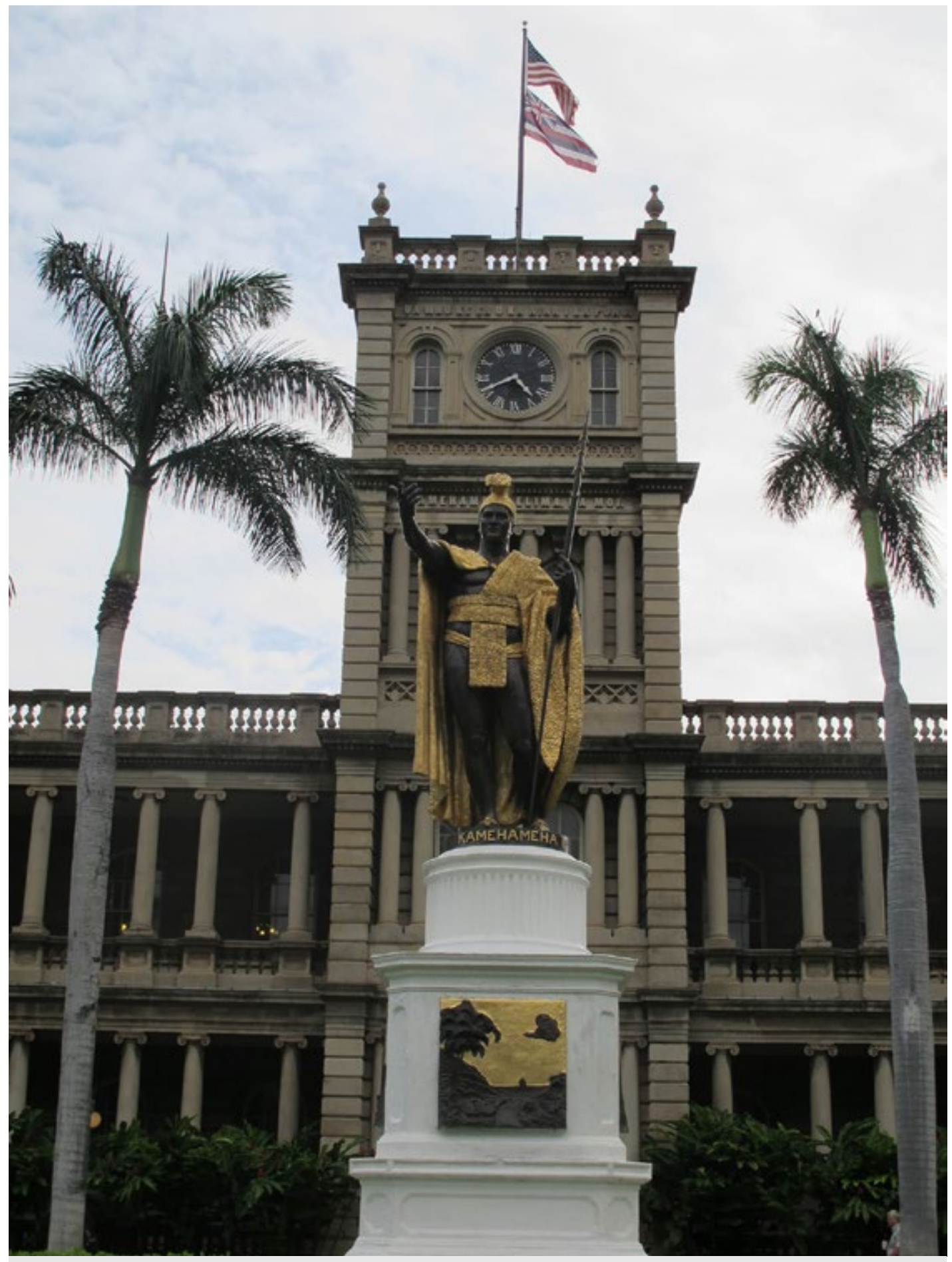

Fig. 15 Statue of Kamehameha I in front of Hawai'i State Supreme Court (in Ali'iolani Hale), Thomas R. Gould, sculptor, cast bronze, statue dedicated 1883, O'ahu, May 2011. Photo: (c) Sally Promey 


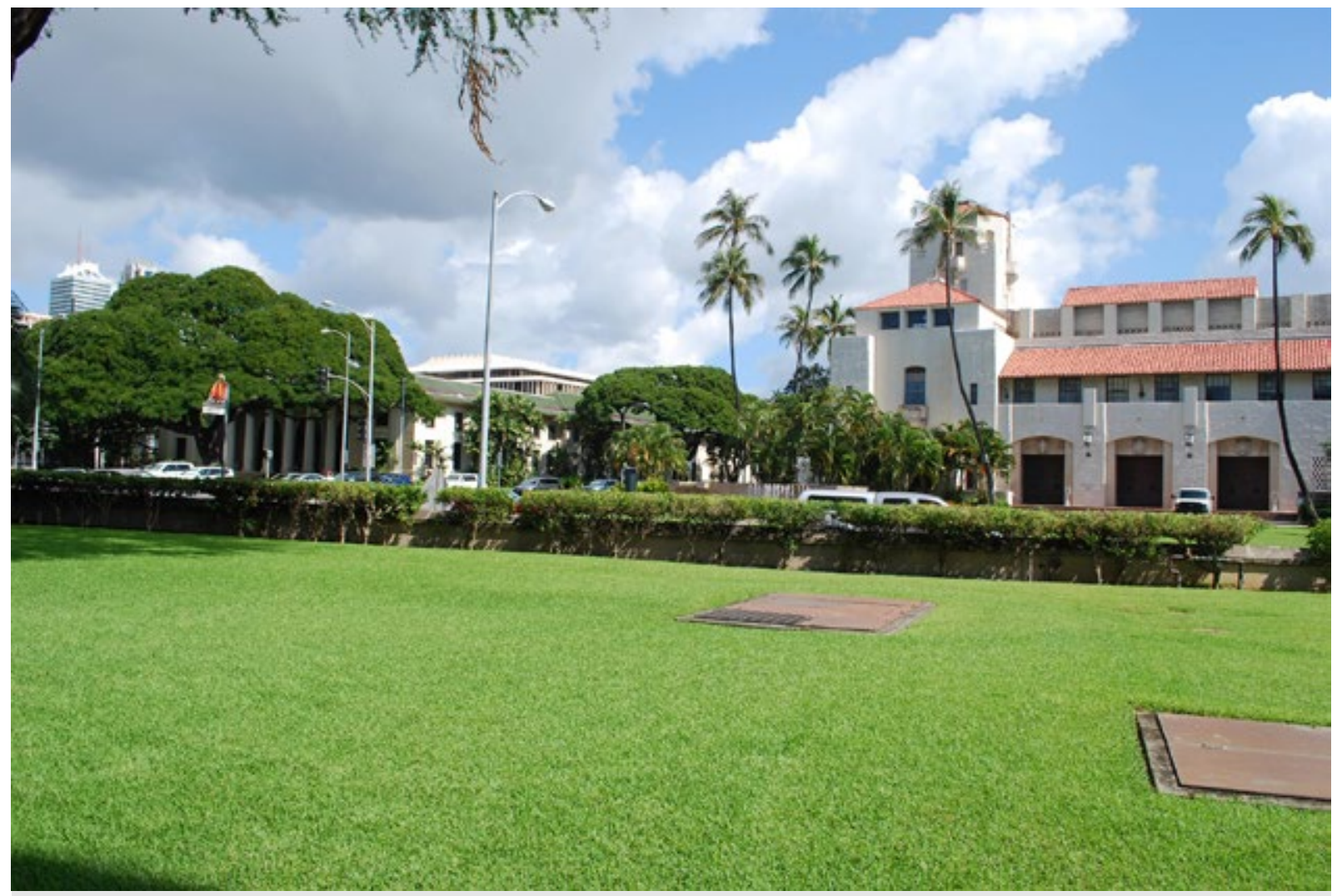

Fig. 16 Hawai'i State Capital, visible in middle distance from main steps of Kawaiaha‘o Church, with Hawai`i State Public Library seen in front of the State Capital, February 2014. Photo: (C) Sally Promey

Other recent cases in Hawai'i unfold in ways that underscore the impact of material establishment. (Here I will simply gesture at one or two.) Each recapitulates and intensifies past conflicts concerning sacred objects made public, their treatment, ritualization, classification, and occupation. Each contest hinges on material religion and disagreements over the impact of disruption and display. Each is a source of considerable distress to various concerned parties. Each embraces and articulates embodied materialities, living objects (bones, stones, and landscapes, for example).

One case currently in the news (at least in so far as anything in Hawai'i ever makes the "national" news) is the critical dispute over the sacred landscape of Mauna Kea (Fig. 17). The Thirty Meter Telescope (TMT) Observatory Corporation, a nonprofit organization funded by universities in the United States, China, Japan, India, and Canada, proposes to build a telescope that would join thirteen others (Fig. 18) on Mauna Kea. This one would be by far the largest: eight acres of surface, eighteen stories high (the tallest building on the island and, by some accounts, the largest telescope on the planet). Mauna Kea, home to gods and goddesses, site of many burials, shrines, altars ('ahu), and ceremonies, is more properly Mauna a Wākea, an embodiment of the male god Wākea, partner of the female Papahānaumoku, first ancestors of the Hawaiian people, the pair from which the islands emerged. Mauna a Wākea, because of its place at the source of the genealogy of chiefs, of Hawaiian stories of origin, is a kupuna, an elder or ancestor. Here again, judicial, nonprofit, and law-enforcement decision-making have privileged understandings of religion (and the religion of science) that left no space for 


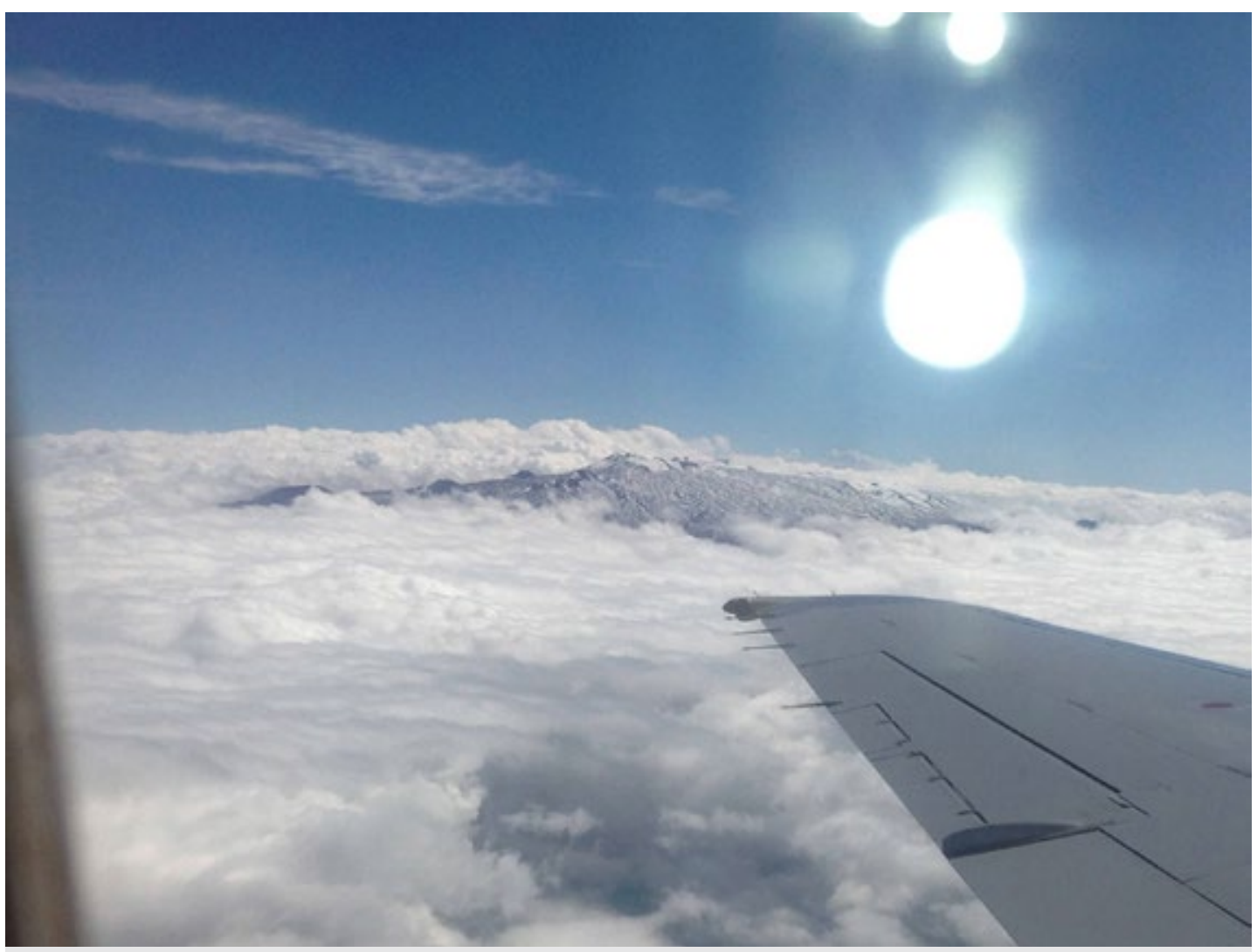

Fig. 17 Summit of Mauna Kea (Mauna a Wākea), Hawai'i Island, seen from airplane, March 2014. Photo: (C) Sally Promey

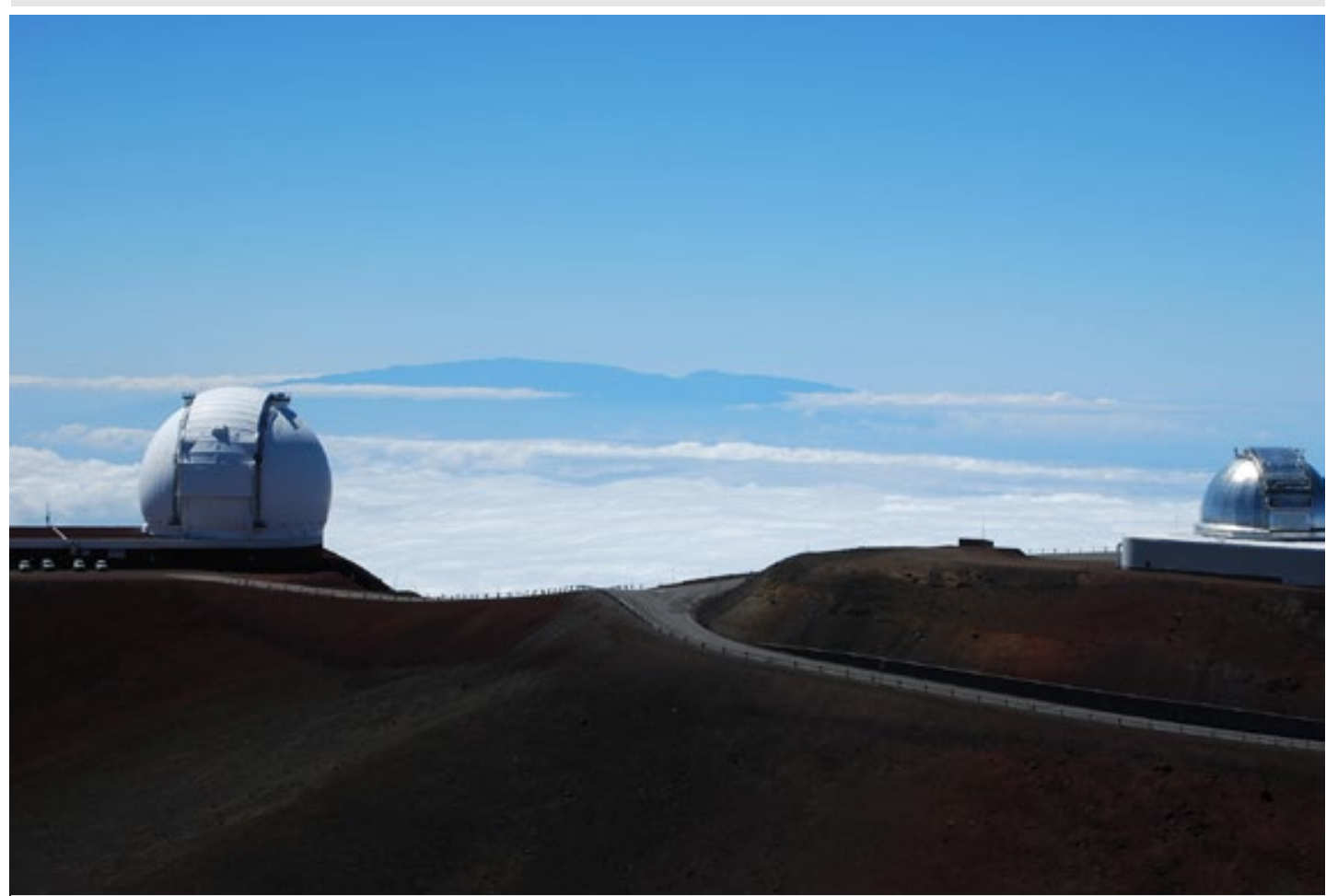

Fig. 18 Summit of Mauna Kea (Mauna a Wākea), Hawai'i Island, showing two observatories, looking toward Haleakala on island of Maui visible in distance, August 2014. Photo: (C) Sally Promey 
this kind of sacred landscape. The summit (the piko; Fig. 19-21) ties earth mother to sky father in ways that appear relatively unmarked to "western" eyes. How can a mountain be a temple? How can it be simultaneously an ancestor? Though ground has already been broken, the State of Hawai'i Supreme Court invalidated the building permit for the site in early December 2015, asserting that the TMT Corporation had not followed due process; thus, by some important measures, the balance seems to be shifting. Protectors (Fig. 22; a name deliberately chosen over "protestors"; Fig. 23) camped out overnight (Fig. 24) on the volcanic mountain from April through September 2015 (when forced to desist), chanting, praying, building 'ahu (Fig. 25), and displaying a Kū ki $i$ ' a sculptural image of one of the four major Hawaiian gods (Kü, god of male generative power). This Kū ki'i is regarded as a specific and new embodiment (kino lau) of Kū named Kūkia'imauna (Kū, Protector of the Mountain). Human protectors have constructed for the Kū ki'i its own hale (Fig. 26), which remains a ritual center for those on the mauna. ${ }^{11}$ Though they have adopted "kapu aloha" or the rule of love, as their strategy, and have proven successful at engaging positive social media attention, many have been arrested. In September, a "rogue" employee of the State bulldozed the legally sited 'ahu (shown in Fig. 25) at which this community had been conducting religious ceremonies. The videotape of the aftermath is heartbreaking. The tent has been removed (19 September 2015) and the hale for Kū has been challenged by the State. For my work, and in respect to material establishment, this raises the question: What is "religion in plain view" when it doesn't "look like" "religion"? A similar case is unfolding on Haleakalā (Fig. 27) on the island of Maui.

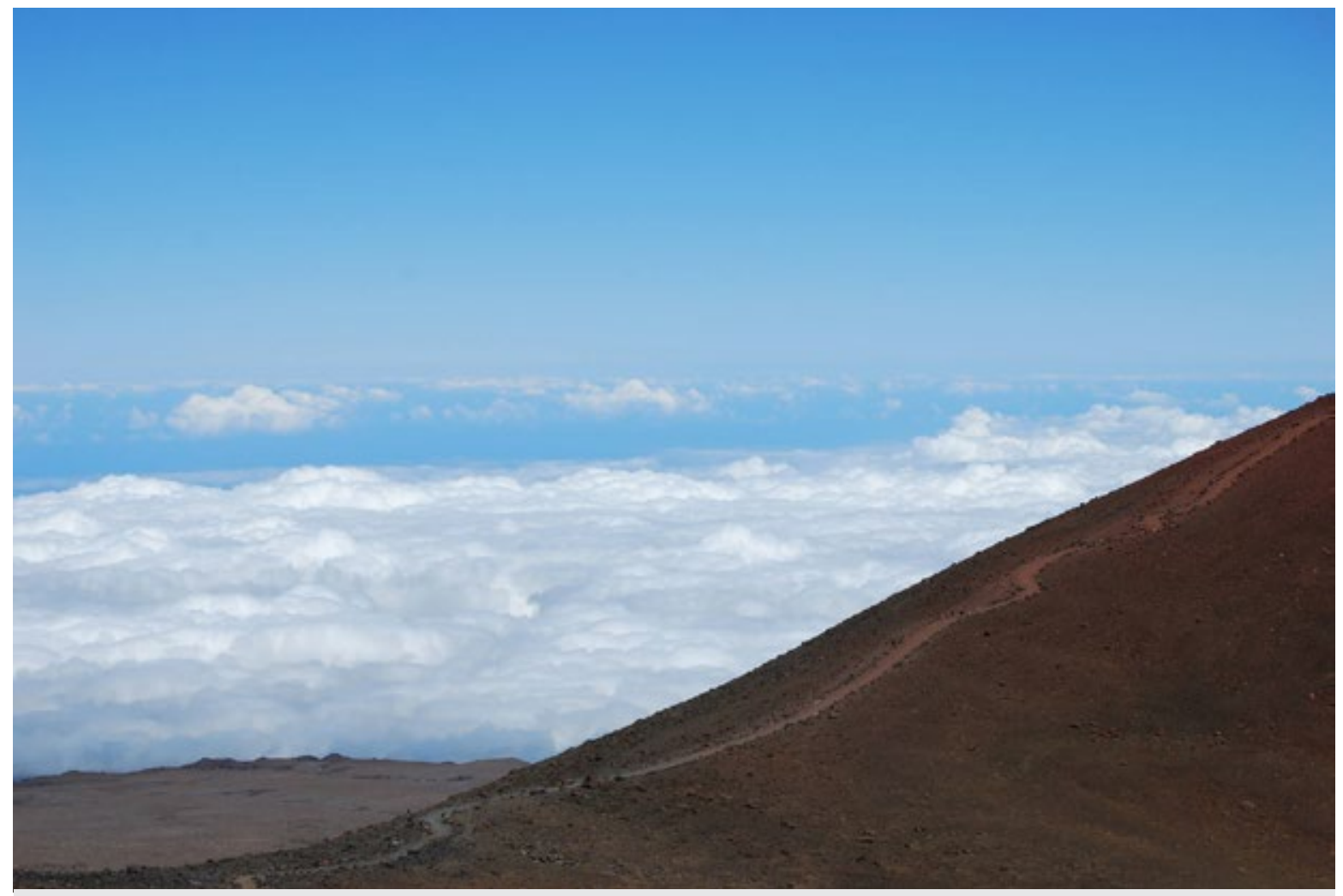

Fig. 19 Summit of Mauna Kea (Mauna a Wākea), Hawai'i Island, trail to summit at its highest point, August 2014. Photo: (C) Sally Promey 


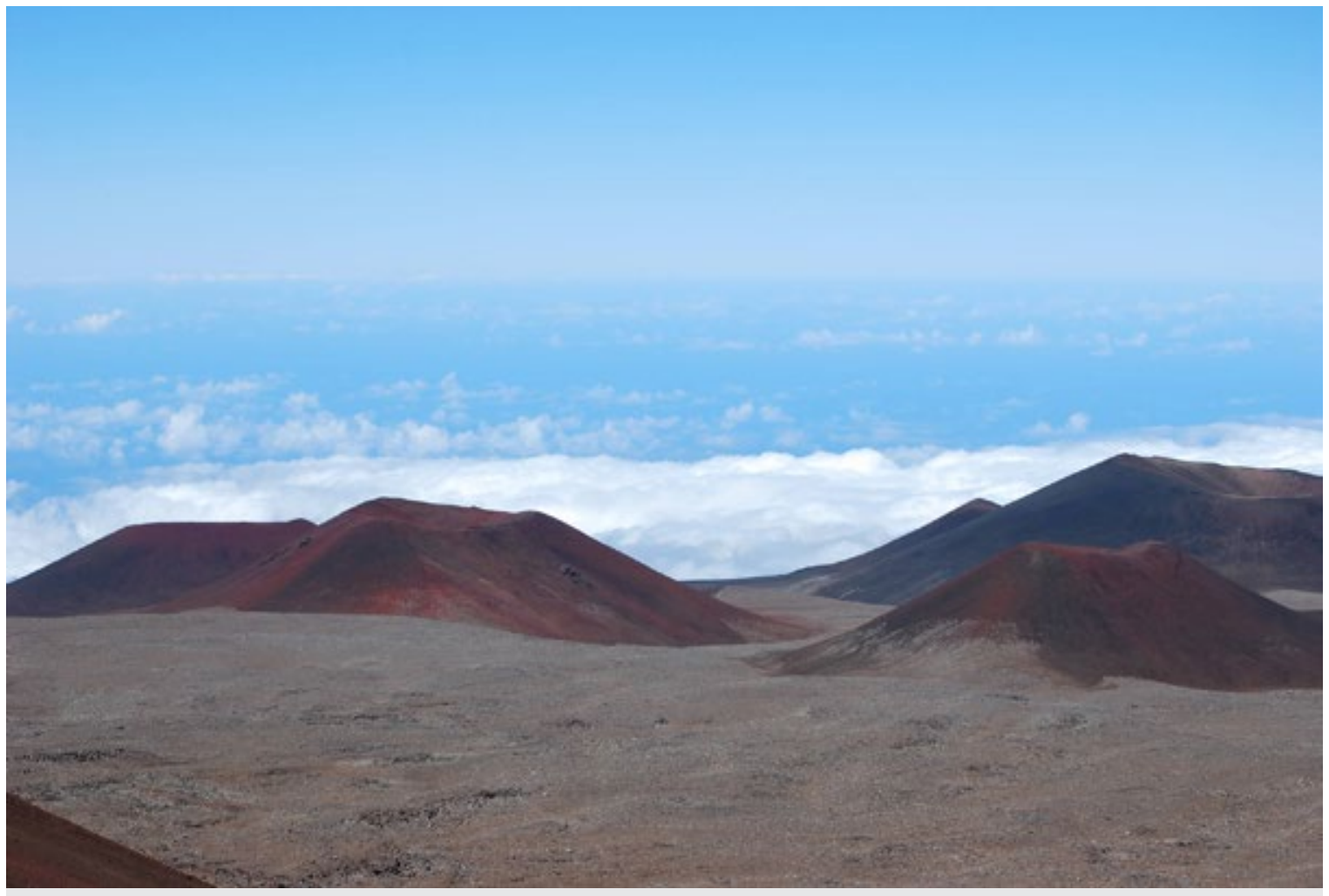

Fig. 20 Summit of Mauna Kea (Mauna a Wākea), Hawai'i Island, summit landscape, August 2014. Photo: (C) Sally Promey

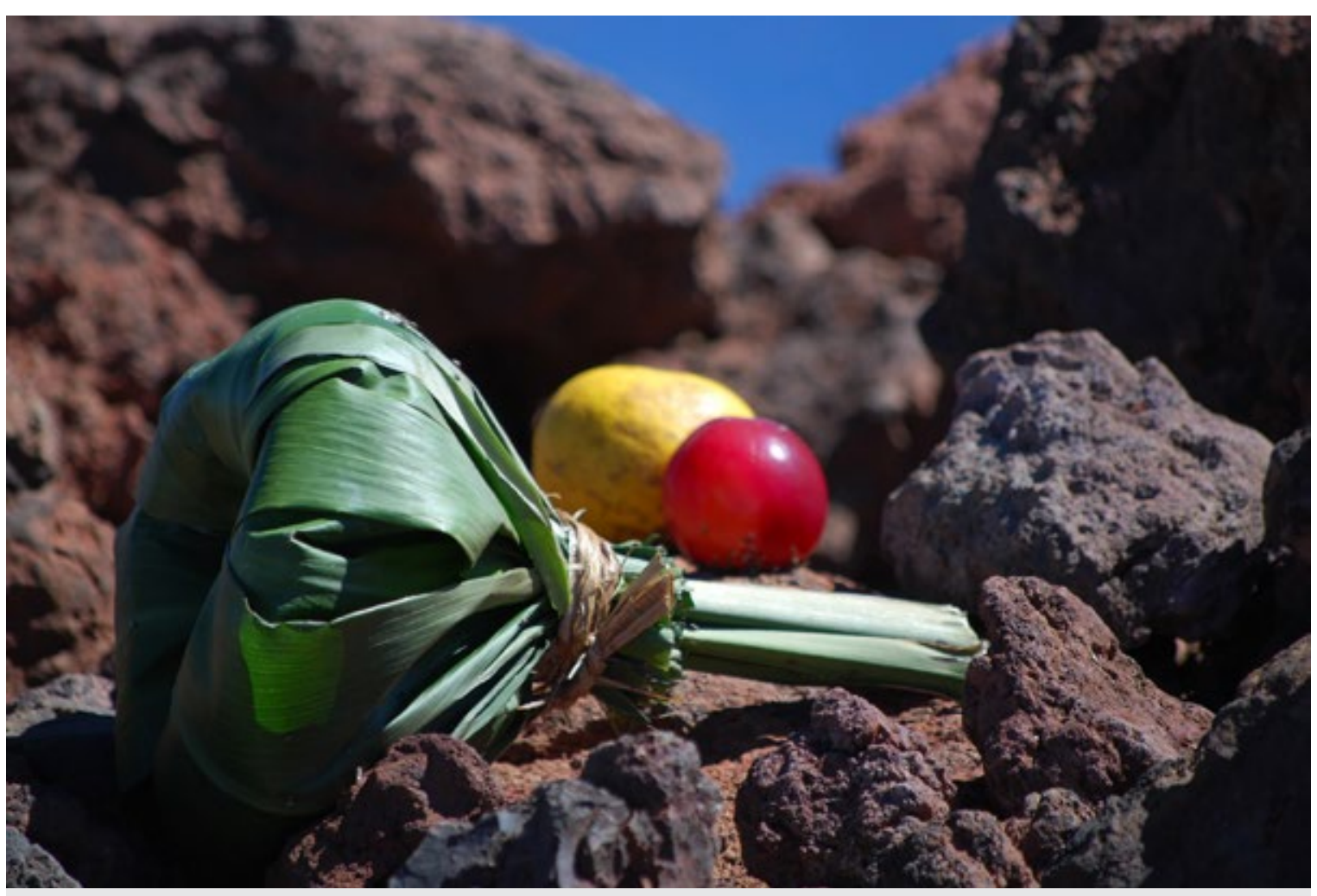

Fig. 21 Offerings at 'ahu at highest point of summit of Mauna Kea (Mauna a Wākea), Hawai'i Island, August 2014. Photo: (C) Sally Promey 


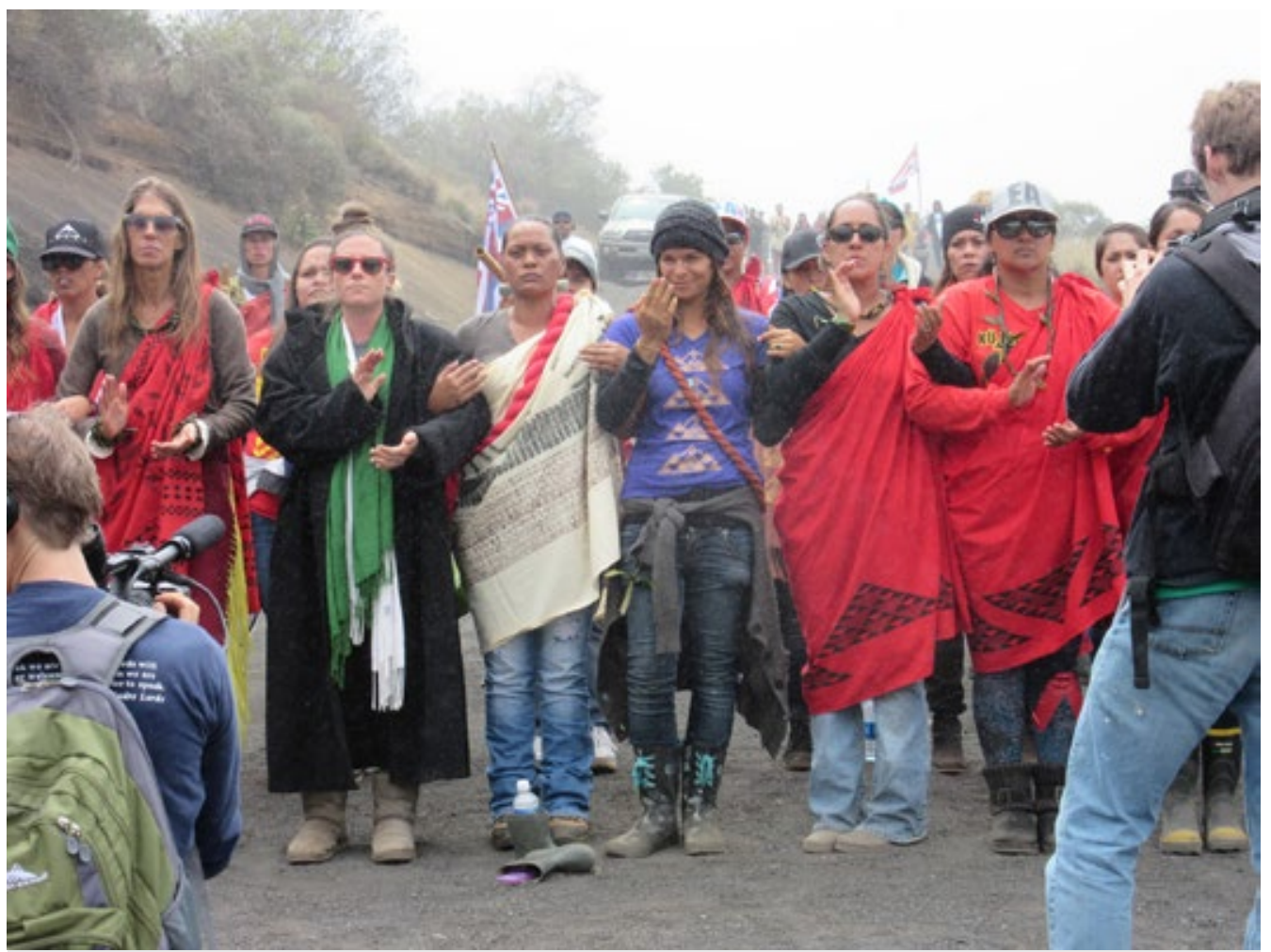

Fig. 22 Protectors on Mauna Kea (Mauna a Wākea), Hawai'i Island, June 2015. Photo: (c) Greg Johnson

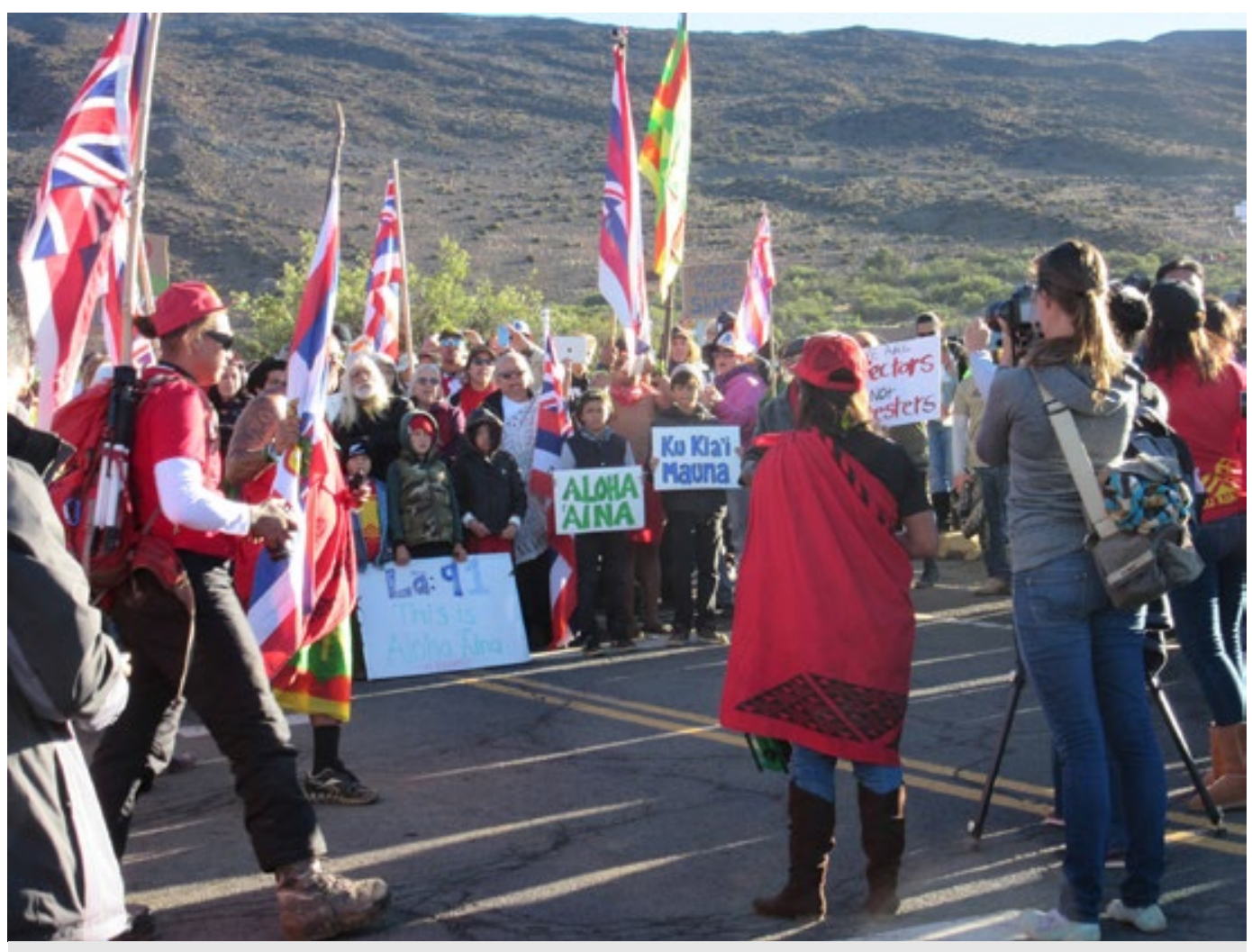

Fig. 23 Protectors on Mauna Kea (Mauna a Wākea), Hawai'i Island, with signage "We are Protectors, not Protestors," June 2015. Photo: (c) Greg Johnson 


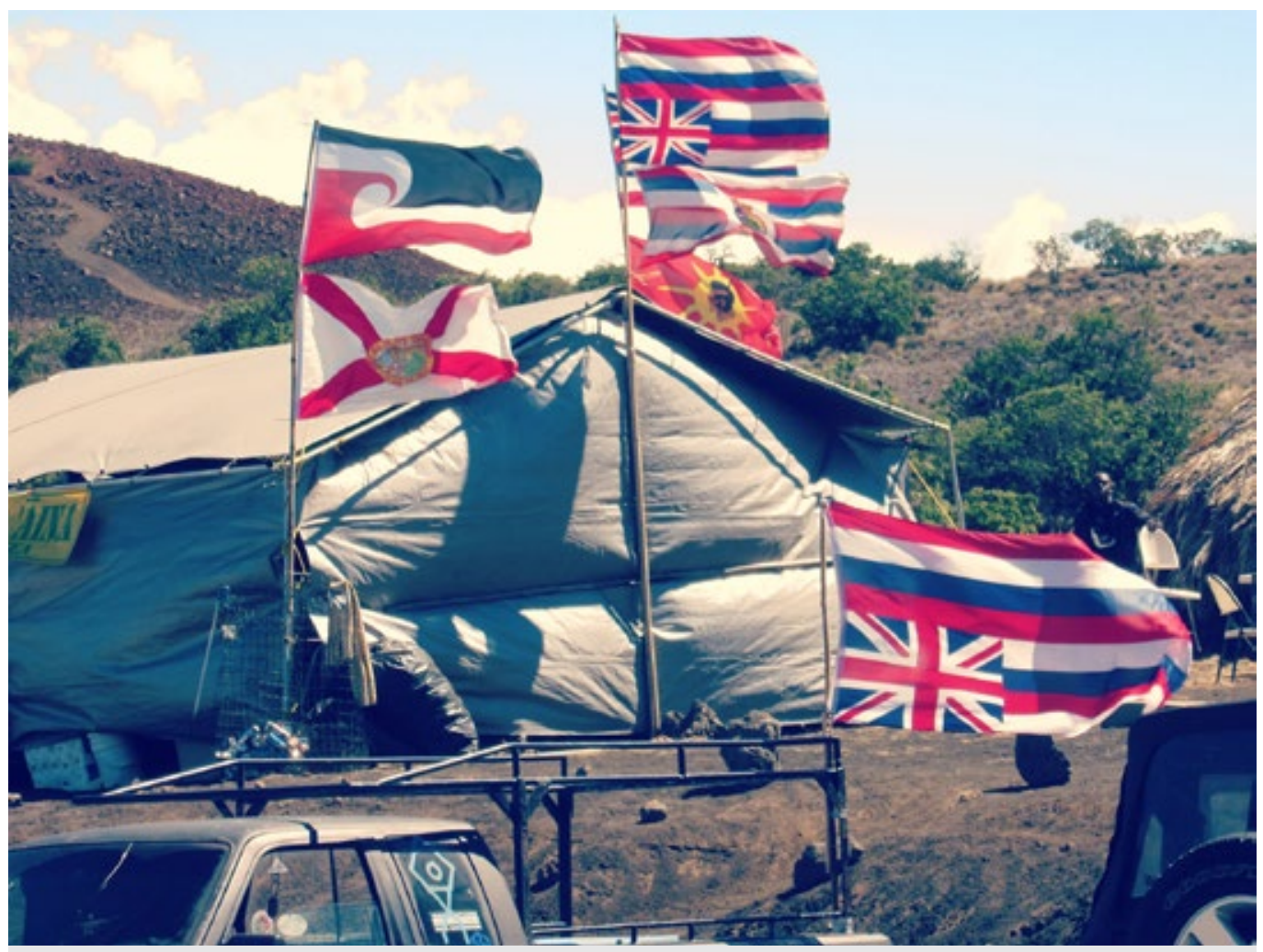

Fig. 24 Protectors camp on Mauna Kea (Mauna a Wākea), Hawai`i Island, flags hung upsidedown as signal of distress, June 2015. Photo: (C) Greg Johnson

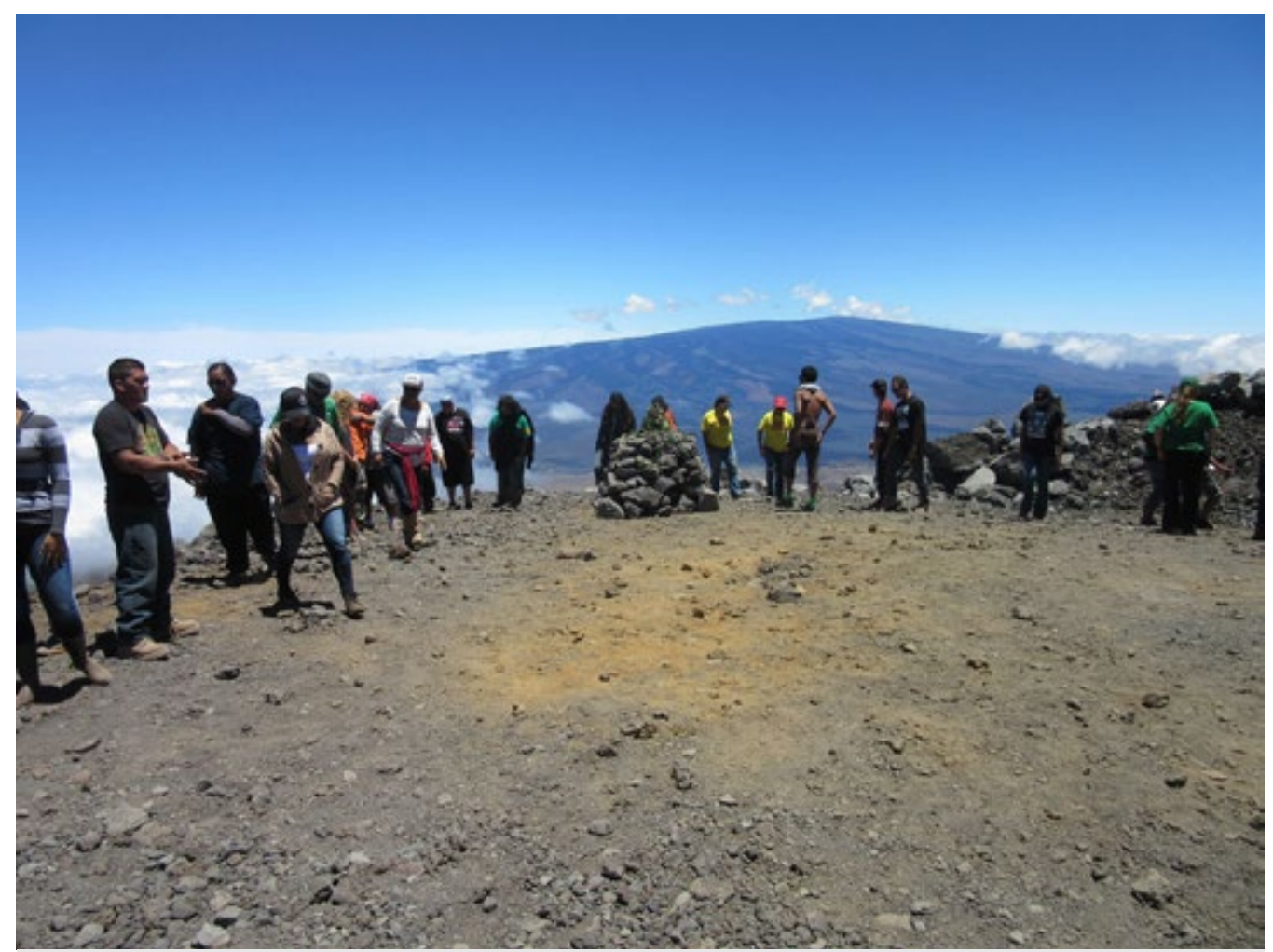

Fig. 25 ‘Ahu on Mauna Kea (Mauna a Wākea), Hawai‘i Island, June 2015. Photo: (c) Greg Johnson 


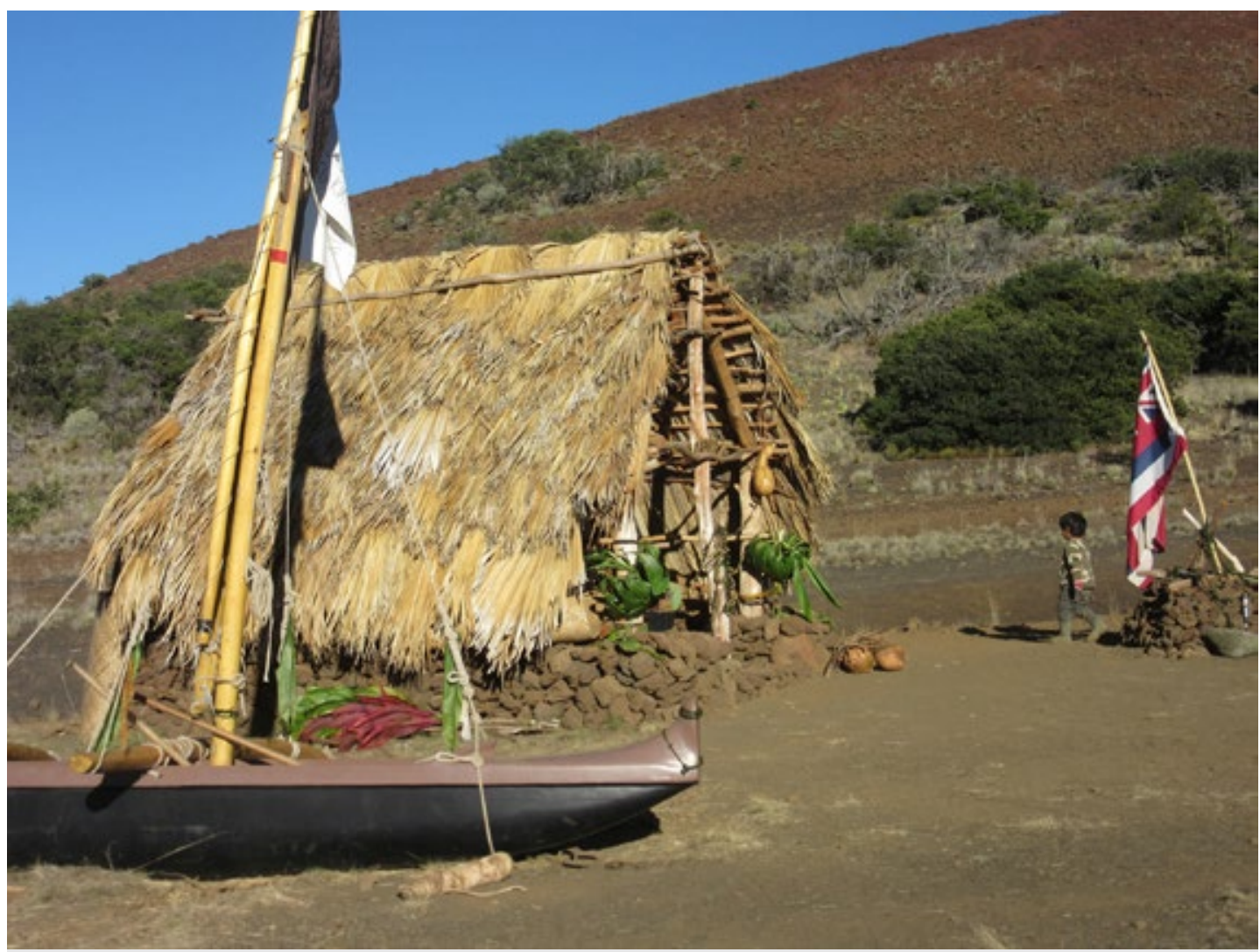

Fig. 26 Kū Hale on Mauna Kea (Mauna a Wākea), Hawaíi Island, June 2015. Photo: (c) Greg Johnson

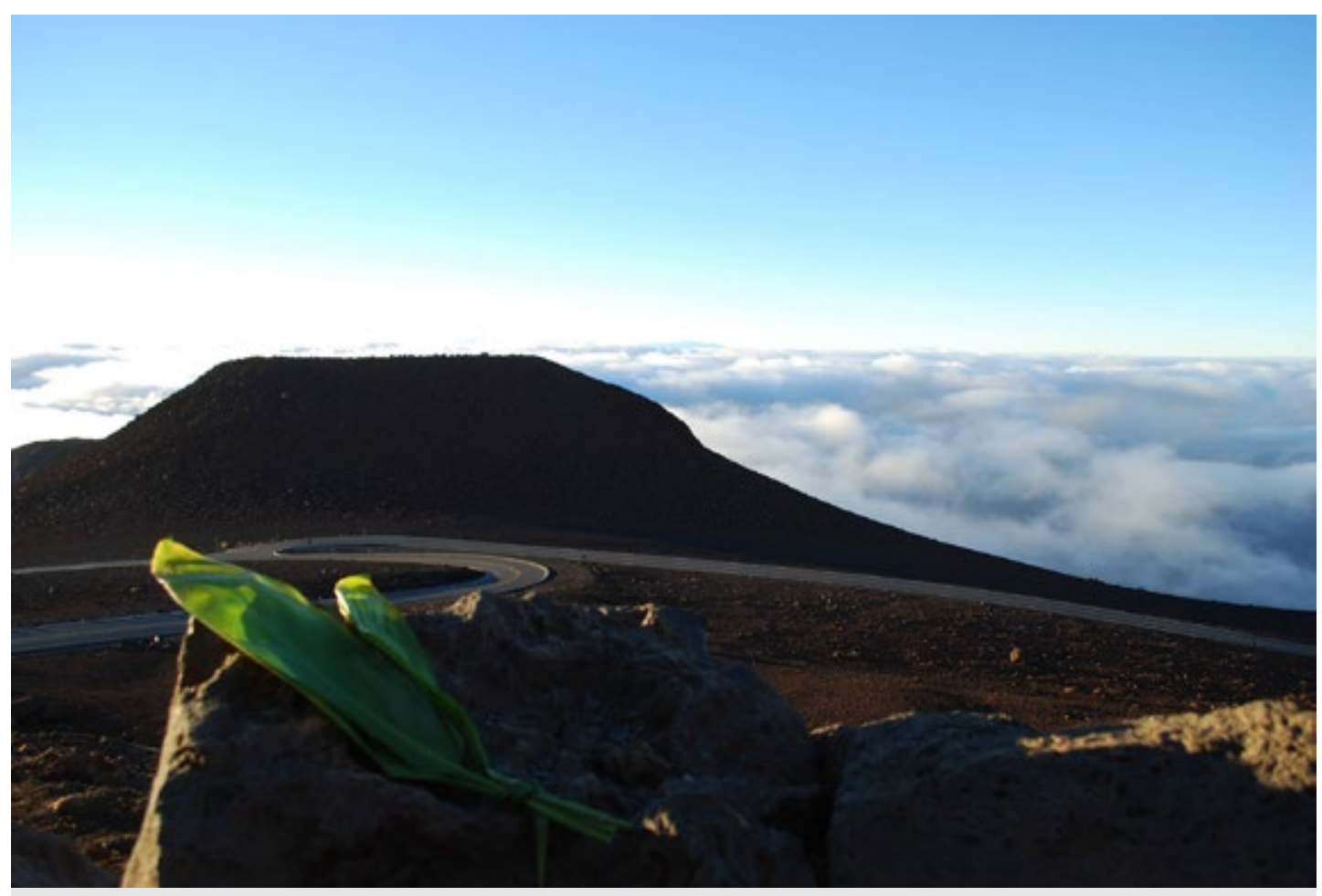

Fig. 27 Offering on summit of Haleakalā, Maui, with summit of Mauna Kea (Mauna a Wākea) in distance, July 2015. Photo: (C) Sally Promey 
Not only as concerns telescopes in sacred high places, but wherever there is development, the islands are marked by attempts to protect ancestral remains and to preserve proper ritual protocols. This repository for remains (Fig. 28; Kāhi Hāli‘a Aloha) in Kapi'olani Park in Waikīkī, immediately adjacent to the Honolulu Zoo (Fig. 29), in full view of Lē'ahi or Diamond Head and just across the main thoroughfare from Waikikì beach, communicates in its contradictory signage (Fig. 30) the historical frequency of desecration and the promise and threat of this impossible impasse. Ancestors (in stone and bone and landscape) and ancestral remains (the status, powers, and care of human bones) figure largely in each of these instances of cultural injury enjoined by material establishment. $^{12}$

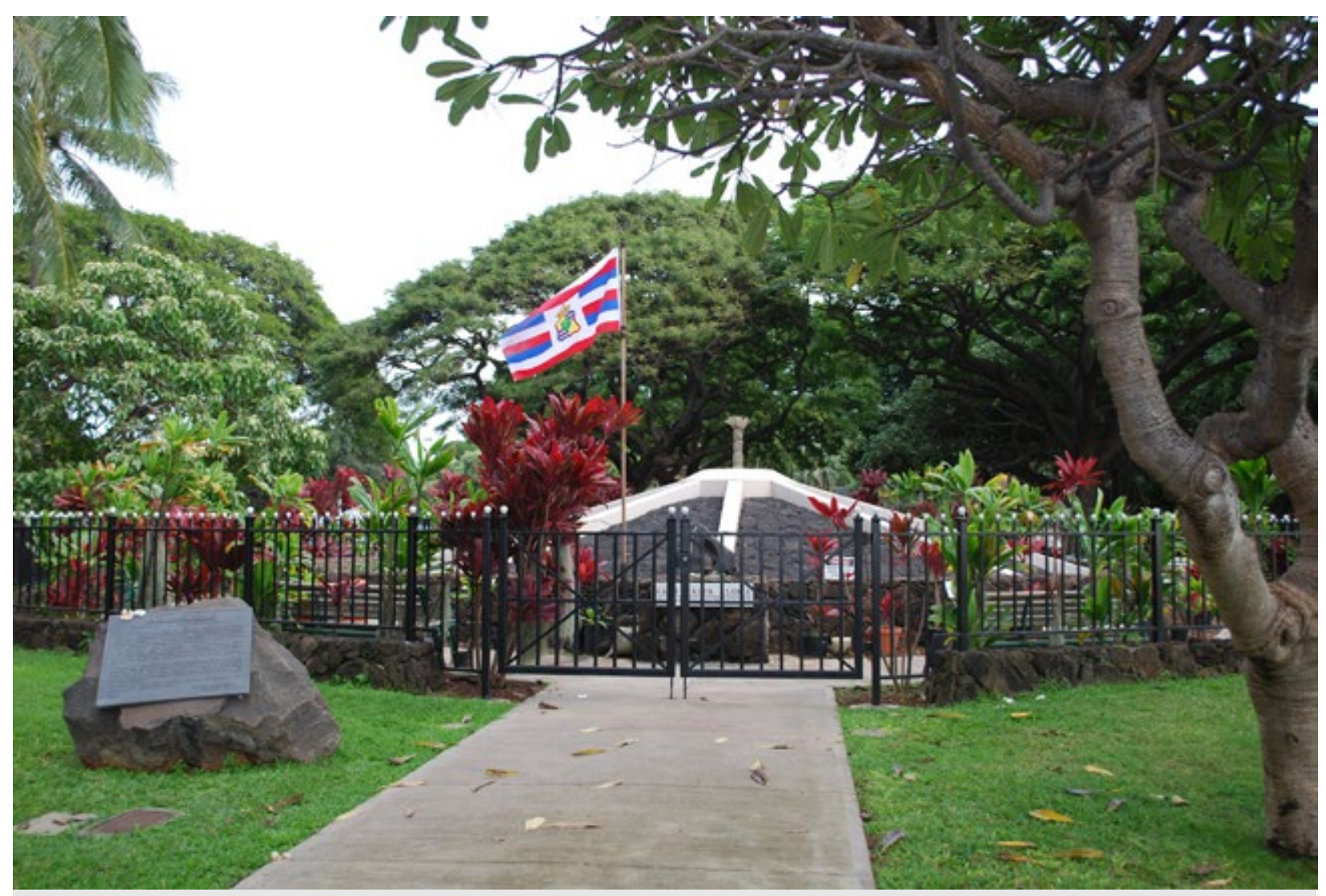

Fig. 28 KĀHI HĀLI‘A ALOHA or Place of Loving Remembrance, burial mound, Kapi‘olani Park, Waikīkī, O‘ahu, February 2014. Photo: (C) Sally Promey 


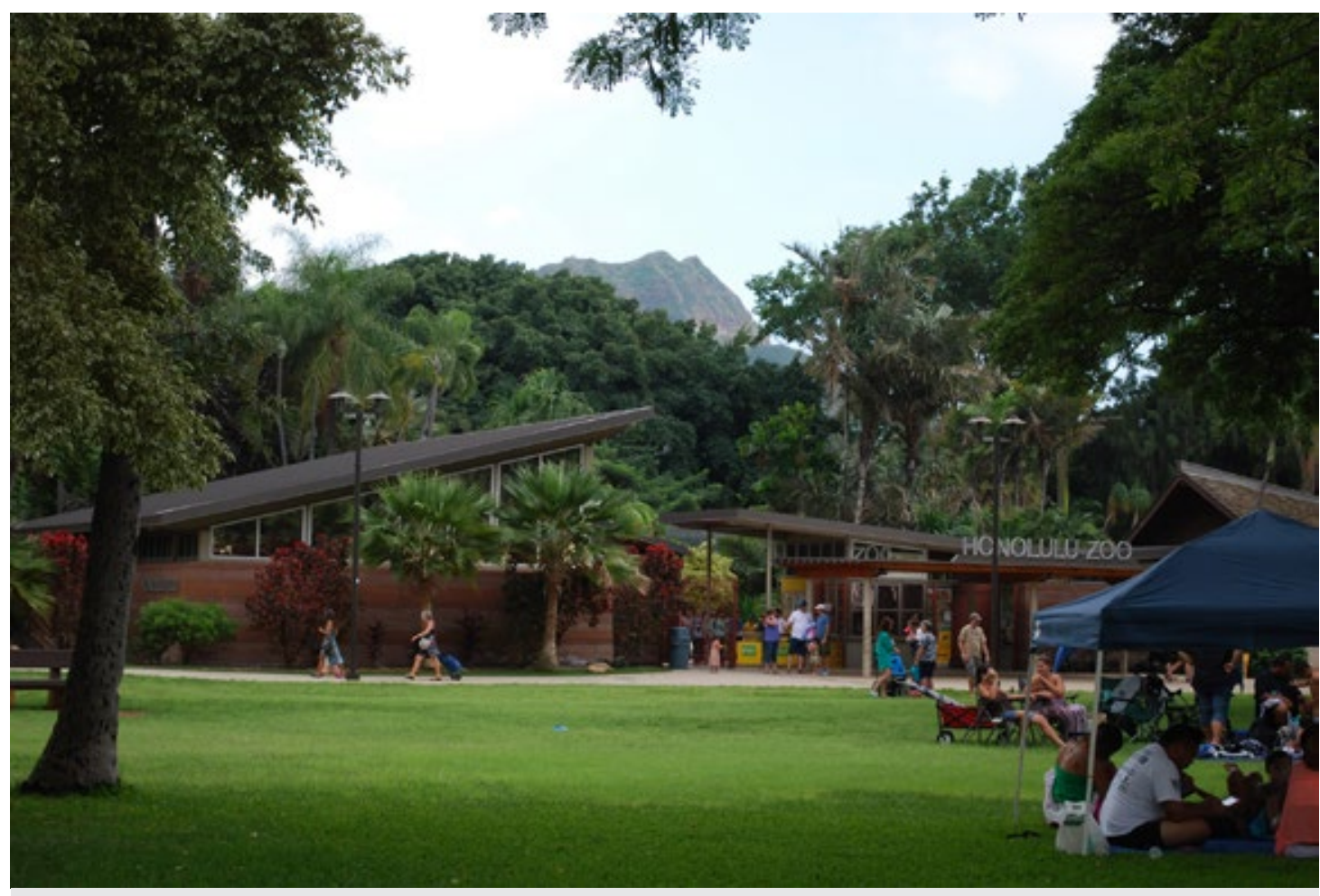

Fig. 29 Honolulu Zoo and Lē'ahi (Diamond Head) seen from Kāhi Hāli‘a Aloha, burial mound, Kapi'olani Park, Waikīkī, O‘ahu, February 2014. Photo: (c) Sally Promey

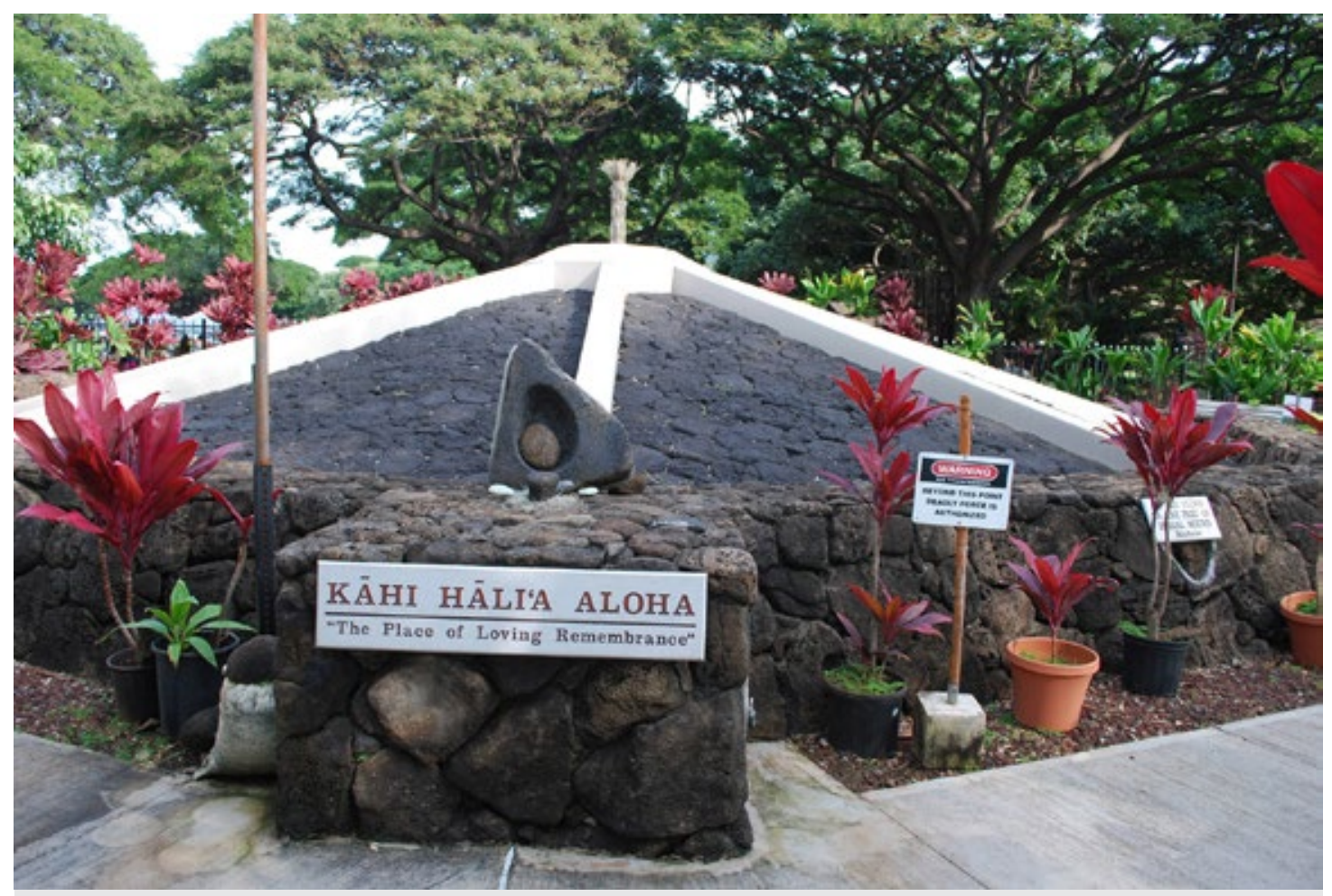

Fig. 30 KĀHI HĀLI'A ALOHA or Place of Loving Remembrance, burial mound, Kapi'olani Park, Waikīkī, O'ahu, showing signage bearing the words "WARNING: BEYOND THIS POINT DEADLY FORCE IS AUTHORIZED,” February 2014. Photo: (C) Sally Promey 
My experience in Hawai'i has led me to reconsider these matters elsewhere in the United States. Holiday displays temporarily (but also repetitively) materialize and thus reveal an underlying set of assumptions about religious and cultural normativity that are less visibly present, but present nonetheless, throughout the year. A lighted nativity scene staked out space on the steps of the Denver City and County Building in December 2014 (Fig. 31). In New Haven, Connecticut, the immediate view from the New Haven County Courthouse steps takes in the town green where, in mid-December 2015, a giant brightly lighted Christmas tree and a neon blue Hanukkah menorah (with seven of its nine candles illuminated), decorated a large open space architecturally marked by three, and only three, prominent buildings, all of them large Protestant churches, active congregations (one Episcopal and two United Church of Christ) that form an important part of the city's history. In many places around the United States during the winter holiday season, American pluralism's placement of a Hanukkah menorah "on the public square" adjacent to a large Christmas tree (Fig. 32) reasserts the explicitly religious identity of a symbol long posed as secular. The menorah accomplishes this by stating its own Jewish religious identity claims in immediate juxtaposition to the evergreen's "Christian" ones.

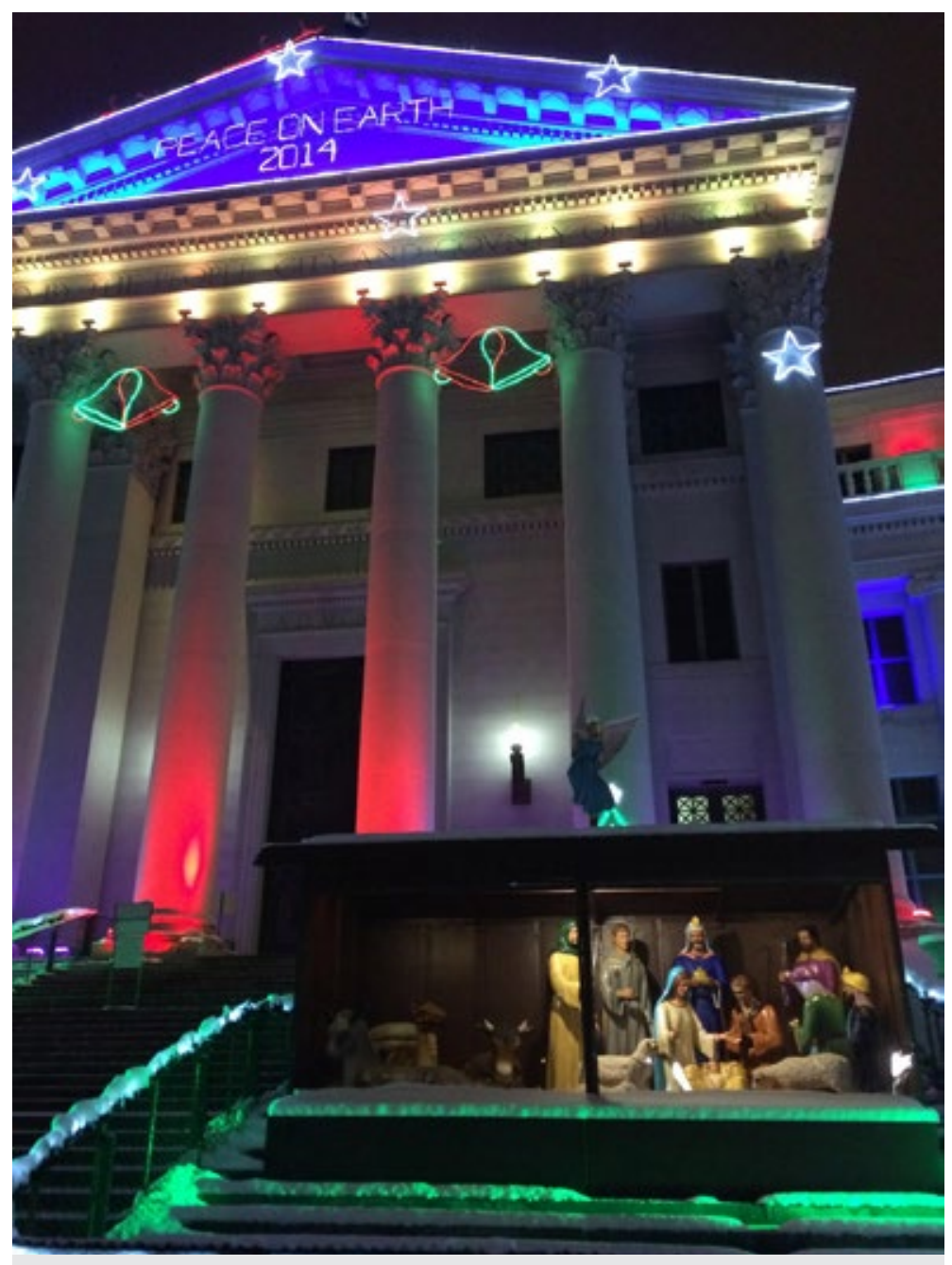

Fig. 31 Christmas Display, Denver City and County Building, Denver, Colorado, December 2014. Photo: (C) Margaret Olin 


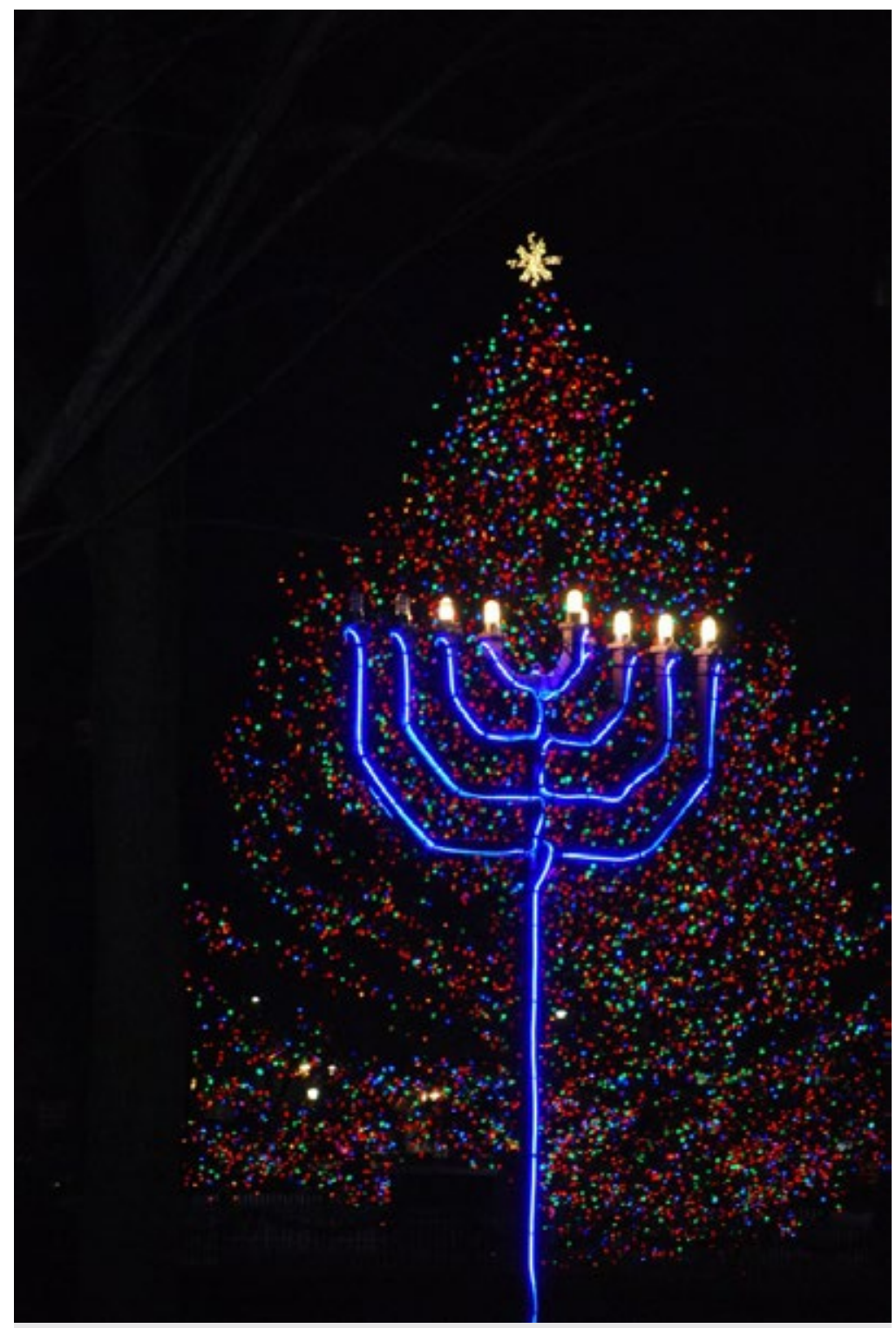

Fig. 32 Christmas Tree and Hanukkah Menorah on New Haven Green, New Haven, Connecticut, December 2015. Photo: (C) Sally Promey

Here, as in Honolulu, the kind of prior presence on the land granted by the colonial settlement of these churches on this central highly visible urban space, near the public library and courthouse and, in New Haven, close to other Protestant religious structures, maintains a hold on the American religious imaginary. I would argue that it does so in such a way, and over time, as to elicit subtle, pervasive, generally unconscious bias in governance, perhaps especially in the judiciary. This is one manifestation of the operations of material establishment. ${ }^{13}$

Key architectural monuments of national history also sustain material establishment. The history painted in the United States Capitol Rotunda's murals represents, among other things, and specifically in their representations of the Baptism of Pocahontas and the Embarkation of the Pilgrims, Protestant claims on nation formation. The art 
and architecture of many post offices, town halls, state houses, public libraries, and courthouses replicate this Christian claim on the American past and present. This is especially the case, for example, in interior murals, largely painted in the first half of the twentieth century, representing various aspects of national history, where the spire of the Protestant church stands in for religious devotion (at least presumably) more broadly construed. Importantly, material establishment, in the form of public display, takes shape on private property as well as public land. ${ }^{14}$ Zoning regulations, introduced in the first half of the twentieth century contributed to the proximity of churches to public schools, for example, especially at mid-century in a period of expansion in urban and suburban church building programs, since these two sorts of structures were deemed suitable to areas otherwise zoned residential. Furthermore, the vertical punctuation of church steeples on the actual visible horizon in many parts of the nation testifies to civic identities in ways that contribute to expectations and shape assumptions that inform decision-making. ${ }^{15}$

Preservation of historic religious buildings and monuments both creates a normative history and maintains "heritage" and memorial presence on the land (Figs. 33 and 34). ${ }^{16}$ As evident in the case of Hawai'i, however, preservation, reiteration (in revival styles and advertising, for example), and destruction occur selectively. Some histories are memorialized while others are neglected or forgotten. This kind of selectivity is not neutral but shapes the histories that can be recollected, the identities that can be most publicly considered American. It pays to question the influence of received knowledge in this regard: to ask what religious traditions or entities have been denied space as well as allowed it and what groups have been simply, and literally, overlooked as a (perhaps mostly unintended) feature of settlement patterns. It is, furthermore, useful to consider what individuals and groups have never dared ask for spatial recognition of this sort.

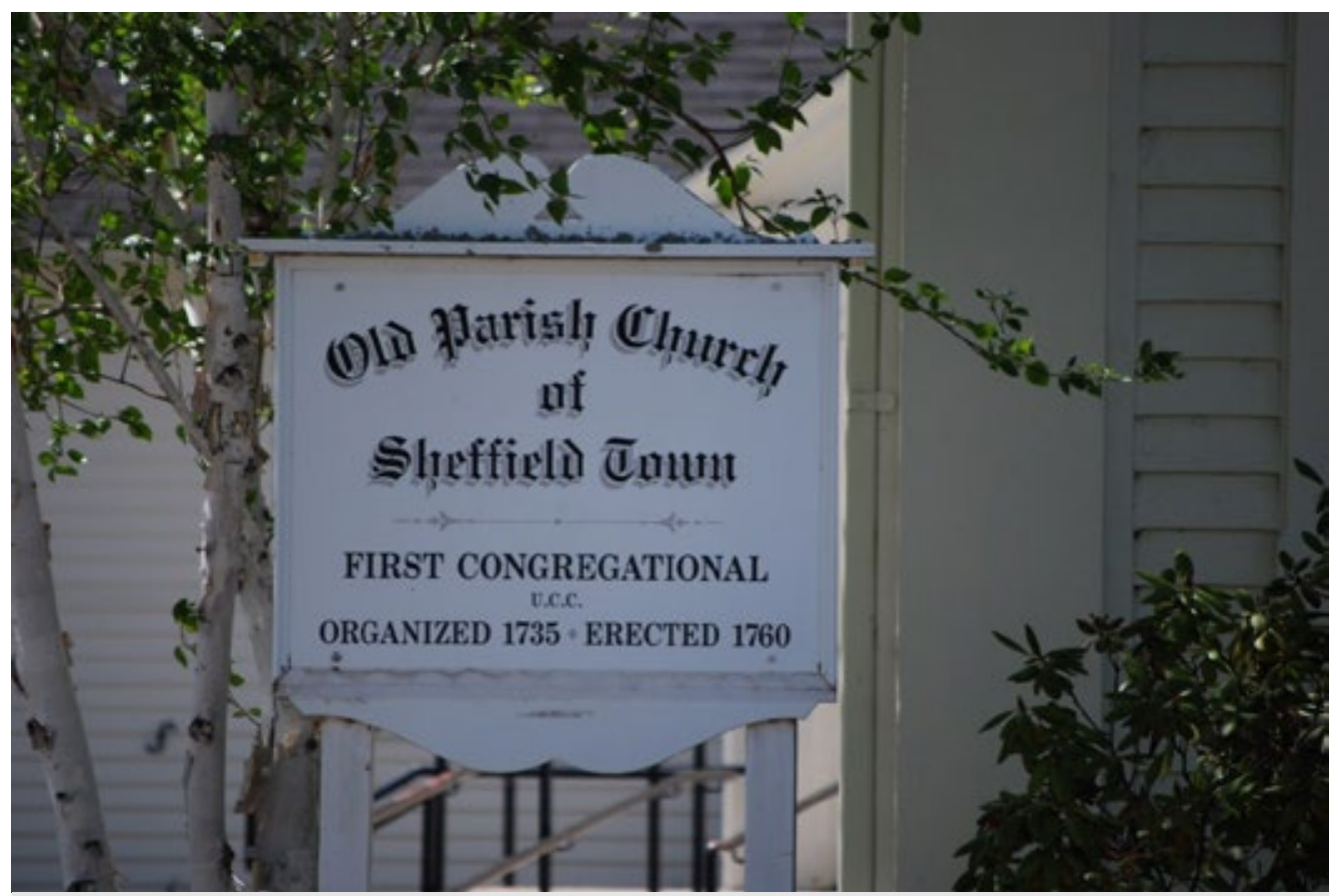

Fig. 33 Signage at Old Parish Church, Sheffield, Massachusetts, May 2014. Photo: (c) Sally Promey 
My point is neither to deny historical records and historical realities nor to recommend destruction or relocation of historical buildings, landscapes, and displays. My point is rather to urge that, as members of communities and as citizens of the United States, as educators and historians, we learn to understand and to teach the implications and import of decisions about presence and preservation, that we carefully attend to these processes of selection, the assumptions behind them, their authorities and personnel, and their outcomes.

The point is to see and understand the ways material establishment (and thus the distribution of power) is instantiated through settlement patterns, mere presence, zoning practices, regulation, access, preservation, and display. The material and spatial environment, its construction, maintenance, reconfiguration, and/or destruction, elicits, directs, and constrains imagination and historical understanding.

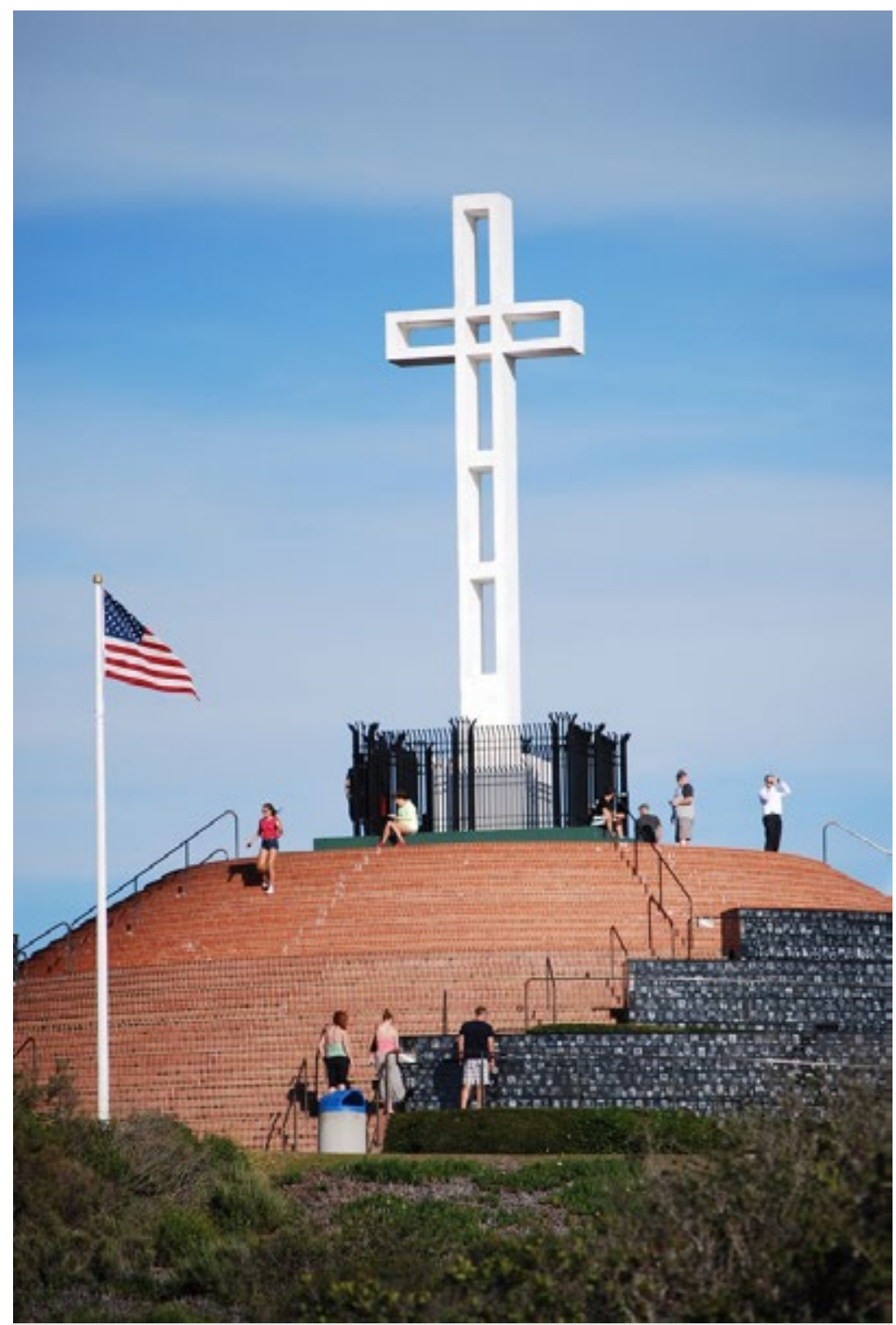

Fig. 34 Mount Soledad Veterans Memorial, San Diego, California, March 2015. Photo: (C) Sally Promey 
(C) Sally M. Promey

\section{Citation Guide}

1. Sally M. Promey, "Material Establishment and Public Display," Mediation, in Conversations: An Online Journal of the Center for the Study of Material and Visual Cultures of Religion (2016), doi:10.22332/con.med.2016.2

Promey, Sally M. "Material Establishment and Public Display." Mediation. In Conversations: An Online Journal of the Center for the Study of Material and Visual Cultures of Religion (2016). doi:10.22332/con.med.2016.2

\section{Notes}

1. The book is titled Religion in Plain View: The Public Aesthetics of American Belief. I first publicly ventured the notion of "material establishment" in several talks presented between early September and late October 2015, among these "Embodied Spaces, Populated Object, and Matters of Dispute: Case Studies in Hawai'i" for the Material Religion conference at Duke University and "Disputed Matter: Spatial Performance, Material Authority, and Religious Practice in Hawai'i” for the annual meeting of the American Studies Association in Toronto, Canada.

2. And see Jonathan Kay Kamakawiwo'ole Osorio, Dismembering Lahui: A History of the Hawaiian Nation to 1887 (Honolulu: University of Hawai'i Press, 2002).

3. Ty Tengan, Native Men Remade: Gender and Nation in Contemporary Hawai $i$ (Durham, NC: Duke University Press, 2008).

4. Greg Johnson, "Varieties of Native Hawaiian Establishment: Recognized Voices, Routinized Charisma, and Church Desecration," in Winnifred Fallers Sullivan and Lori G. Beaman, eds., Varieties of Religious Establishment (Farnham, England: Ashgate, 2013), 55-71.

5. Ibid., 55-56.

6. Ibid., 56.

7. Ibid., 61.

8. See Johnson, 56, note 3 .

9. While the camera angle makes this difficult to discern, the " $\mathrm{e}$ " is smaller than the other capital letters thus marking out two words: Ke Akua (The God), rendered on the stone as KEAKUA. It is not uncommon in Hawai'i for words to be run together like this; 
I thank Greg Johnson for this information.

10. Visit the Kawaiaha'o Church's home page here: perma.cc/AMV9-7LAZ

11. The hale is called Hale Kūkia'i Mauna. See here (https://www.youtube.com/ watch?v=Ld2MiqvqyLU) for a video of the erection of Hale Kūkia'i Mauna.

12. As Johnson points out in "Varieties of Religious Establishment," not all religious establishment in Hawai'i or elsewhere in the United States is material establishment. At Pu'ukoholā, a major Hawaiian heiau (temple) site, the State, under the auspices of the National Park Service, and in order to avoid perceived violations of the establishment clause, names indigenous religious observance as other than "religious," as cultural performance in the context of tourist educational fair or festival. Given the categorical impossibility of separating Hawaiian religion from Hawaiian culture, what results is an artificial distinction that rapidly dissolves but that, as framed by the park service, also produces conditions that undermine indigenous authority and seem likely to dissuade participation over time. I will have much more to say on this subject in Religion in Plain View.

13. In New Haven, this material presence is further secured by the gothic revival architecture of Yale University, an historic bastion of Protestant, white, male privilege and power; and see Sullivan, Impossibility of Religious Freedom, 4-8.

Another example of material establishment, as related to the judiciary in particular, concerns the traditional (now optional) ritual practice of swearing on the Christian bible the truthfulness of one's subsequent utterance prior to giving testimony in court.

14. In my work on public display, I mean to center attention on religion's visual and material embodiments and enactments in the spaces we inhabit and traverse in the usual conduct of our daily routines. I have in mind public display of a particular sort: display that is set out for generalized others to see in the course of fairly ordinary, fairly everyday circumambulations of common spaces, spaces to which the designers and practitioners of display assume that most everyone has, or can have, easy visual access. In the most fundamental sense, I am articulating the "public" in public display not as the exclusively governmental or civic but as the commonly visible and accessible. I consider material religion's modes of public address, the ways religion looks and works in public space.

15. That Protestant Christian churches recognized the steeple's ability to solicit attention and recognition is explicitly stated in early twentieth-century advertising manuals; see, for example, Francis H. Case, ed., Advertising the Church: Suggestions by Church Advertisers (New York: Abingdon Press, 1925): 2 and 22.

16. See Winnifred Sullivan's 5 May 2010 posting in The Immanent Frame's "Rethinking Secularism series: Sullivan, "The Cross: More Than Religion?" http://blogs.ssrc.org/tif/2010/05/05/more-than-religion/ 
Religion and culture are very slippery categories. Each is deployed, often with respect to the other, to a variety of ends; each is consequential in terms of how we mark some things for preservation and yet neglect to even notice others. Indigenous Hawaiians find that observances that actually defy as well as blend the two categories must submit to "cultural" classification, and the touristic intrusions that accompany it, in order to take place on native lands now "owned" by the National Park Service. "Ethnic" Christianities celebrated as "culture" rather than religion by civic organizations all over the United States assume largely unmonitored public presence. In the latter case, this is not to recommend otherwise but simply to note what is omitted and what reinforced by these practices vis-à-vis prevailing understandings of the boundaries of diversity marked for recognition as part of American national formations.

\section{Yale}

Copyright 2016 Yale University All rights reserved. 